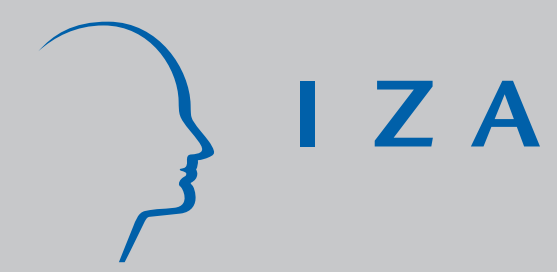

IZA DP No. 1315

The Dynamic Impact of Immigration on Natives' Labor Market Outcomes: Evidence from Israel

Sarit Cohen-Goldner

M. Daniele Paserman

September 2004 


\title{
The Dynamic Impact of Immigration on Natives' Labor Market Outcomes: Evidence from Israel
}

\author{
Sarit Cohen-Goldner \\ Bar-Ilan University \\ M. Daniele Paserman \\ Hebrew University, CEPR \\ and IZA Bonn \\ Discussion Paper No. 1315 \\ September 2004
}

\author{
IZA \\ P.O. Box 7240 \\ 53072 Bonn \\ Germany \\ Phone: +49-228-3894-0 \\ Fax: +49-228-3894-180 \\ Email: iza@iza.org
}

Any opinions expressed here are those of the author(s) and not those of the institute. Research disseminated by IZA may include views on policy, but the institute itself takes no institutional policy positions.

The Institute for the Study of Labor (IZA) in Bonn is a local and virtual international research center and a place of communication between science, politics and business. IZA is an independent nonprofit company supported by Deutsche Post World Net. The center is associated with the University of Bonn and offers a stimulating research environment through its research networks, research support, and visitors and doctoral programs. IZA engages in (i) original and internationally competitive research in all fields of labor economics, (ii) development of policy concepts, and (iii) dissemination of research results and concepts to the interested public.

IZA Discussion Papers often represent preliminary work and are circulated to encourage discussion. Citation of such a paper should account for its provisional character. A revised version may be available directly from the author. 


\section{ABSTRACT}

\section{The Dynamic Impact of Immigration on Natives' Labor Market Outcomes: Evidence from Israel*}

This paper studies the dynamic impact of mass migration from the Former Soviet Union to Israel on natives' labor market outcomes. Specifically, we attempt to distinguish between the short-run and long-run effects of immigrants on natives' wages and employment. The transition of immigrants into a new labor market is a gradual process: the dynamics of this process come from immigrants' occupational mobility and from adjustments by local factors of production. Natives may therefore face changing labor market conditions, even years after the arrival of the immigrants.

If immigrants are relatively good substitutes for native workers, we expect that the impact of immigration will be largest immediately upon the immigrants' arrival, and may become smaller as the labor market adjusts to the supply shock. Conversely, if immigrants upon arrival are poor substitutes for natives because of their lack of local human capital, the initial effect of immigration is small, and the effect increases as immigrants acquire local labor market skills and compete with native workers. We empirically examine these alternative hypotheses using data from Israel's Labor Force and Income Surveys from 1989 to 1999.

We find that wages of both men and women are negatively correlated with the fraction of immigrants with little local experience in a given labor market segment. A 10 percent increase in the share of immigrants lowers natives' wages in the short run by 1 to 3 percent, but this effect dissolves after 4 to 7 years. This result is robust to a variety of different segmentations of the labor market, to the inclusion of cohort effects, and to different dynamic structures in the residual term of the wage equation. On the other hand, we do not find any effect of immigration on employment, neither in the short nor in the long run.

JEL Classification: J J00, J30, J61, J21, F22

Keywords: immigration, labor demand, labor supply, segmented labor markets

Corresponding author:

M. Daniele Paserman

Department of Economics

Hebrew University

Jerusalem, 91905

Israel

Email:dpaserma@shum.huji.ac.il

\footnotetext{
* We thank Jennifer Hunt, Magnus Lofstrom, Saul Lach and seminar participants at the European University Institute, Bar-llan University, Ben Gurion University, the University of Haifa, Tel Aviv University and at the IZA Annual Migration Meeting in Bonn (June 2004) for helpful comments. We acknowledge generous financial support from the Maurice Falk Institute for Economic Research in Israel. Stas Krasinski and Royi Ben-Ivri provided excellent research assistance. All errors are our own.
} 


\section{Introduction}

As immigration continues to rise throughout the Western world, the question of the economic impact of immigration on the host country labor market is moving to the center of the public debate. The concern that competition from immigrants may hurt the wages and employment prospects of low skilled natives is among the factors that drive negative attitudes toward immigrants in Europe and the USA. ${ }^{1}$ Despite this widespread sentiment, the economic literature has failed to find conclusive evidence for an adverse effect of immigration on natives' labor market outcomes. In this paper, we try to shed additional light on this issue by studying the impact of the mass migration to Israel of the 1990s. From 1989 to 2000 more than 1 million Jews migrated from the former Soviet-Union (FSU) to Israel, increasing its population and labor force by extraordinary magnitude.

The main novel feature of our work is the attempt to distinguish between the short and long run effects of immigration on the labor market. Much of the existing literature has assumed that the effect of a given immigration wave is uniform over time. However, there are reasons to believe that this is not the case. For example, if immigrants are relatively close substitutes to natives when they land in the host country, we would expect to see an immediate impact on wages and employment, as the stock of capital and other factors of production are fixed in the short run. However, as time goes by, capital and labor adjust, so that the medium and long run response will be smaller, and potentially even zero. An alternative possibility is that upon arrival, immigrants are poor substitutes for native workers, since their imported human capital is not transferable to the host economy (Friedberg, 2000; Eckstein and Weiss, 2003). Therefore, the immediate impact of immigration on natives' labor market outcomes is close to zero; nevertheless, as immigrants acquire local labor market skills, they compete with native workers, so that the medium and long run effects on natives' outcomes might be substantial.

\footnotetext{
${ }^{1}$ Bauer, Lofstrom and Zimmermann (2000).
} 
To tease out these alternative hypotheses, we set up an econometric framework that allows immigrants with different levels of local labor market experience to have different effects on natives' labor market outcomes. The transition of immigrants into a new labor market is a gradual process: the dynamics of this process come from immigrants' occupational mobility and from adjustments by local factors of production. Therefore, natives may face changing labor market conditions, even years after the arrival of the immigrants. While most previous studies implicitly assume that the effect of immigration is homogeneous over time (regardless of whether the time frame of analysis is two or ten years after the arrival of immigrants), we adopt a more flexible approach that nests this conventional assumption.

We use micro data from Israel's Labor Force and Income Surveys from 1989 to 1999 to estimate the impact of the percentage of immigrants with different tenure in Israel in an individual's well-defined labor market segment on natives' wages and employment. The analysis is feasible given the availability of detailed information on dates of immigration in the Israeli data, and the sheer size of the immigration wave, that allows us to observe a sufficiently large amount of immigrants with different amounts of tenure in each labor market segment.

Recognizing that immigrants do not allocate themselves randomly across different labor market segments, we estimate the model using alternative assumptions about the structure of the error term. Specifically, we include segment-specific fixed effects, a segment-specific linear time trend, and higher level fixed effects interacted with a full set of time dummies to control for the potential correlation between immigrant concentration and unobserved labor market conditions.

Following the recent criticisms of the local labor market approach (Borjas, Freeman and Katz, 1996; Borjas 2003), we take particular care to define the segments in such a way that they can be viewed as isolated markets with limited possibilities for native workers to move between them. We consider five definitions of labor market segments in which immigrants and natives may compete: (a) 2-digit occupation cells, (b) residential district interacted with 1-digit occupation, (c) schooling interacted with 
1-digit occupation, (d) 1-digit industry interacted with 1-digit occupation and (e) schooling interacted with experience. According to these definitions, moving across labor market segments involves substantial adjustment costs (education, retraining, moving, commuting, etc.)

Our results indicate that immigration has an adverse short run impact on wages of both men and women, but the effect dissolves in the medium and long run. This result is robust to a variety of different segmentations of the labor market and to alternative structures of the error term. Our preferred estimates suggest that a 10 percent increase in the share of immigrants lowers natives' wages in the short run by 1 to 3 percent. On the other hand, we do not find an effect of immigration on employment, neither in the short nor in the long run.

Our paper is related to the large literature on immigrants' impact on natives' outcomes. It is natural to expect that a large migration wave would have an adverse effect on employment rates and wages of native workers. However, various studies, both in Israel and elsewhere, typically find little or no such effect. Friedberg (2001) studied the impact of FSU immigrants in Israel on the 1989-1994 changes in natives' wages. Taking an instrumental variable approach to control for the occupational selectivity of the immigrants, she shows that the mass migration had no effect on the wages of veteran Israelis. Friedberg's instrumental variable strategy can not be implemented in our setting, because the variable she uses (the occupational distribution of immigrants in the former Soviet Union) can only act as an instrument for immigrant concentration in a cell at a single point in time. In contrast, our goal is to explore the dynamics that arise from immigrants' mobility across segments and over time, and therefore, we take a different approach to control for the selectivity of the immigrants.

Friedberg's results are consistent with much of the international evidence accumulated on the impact of immigration on host country wages and employment. A number of studies exploit variation in immigrant rates across United States cities and over time to measure the impact of immigration on local labor market outcomes 
(Altonji and Card, 1991; Goldin, 1994). These studies typically conclude that immigration had little or no adverse impact on natives' wages and employment. Pischke and Velling (1997) obtain similar results when looking at variation in immigrant rates across German counties. LaLonde and Topel (1991) exploit variation in the timing of immigration across localities to analyze the dynamic substitution patterns between new and older cohorts of immigrants. They find that older immigrants' wages are negatively affected by immigration, whereas natives' wages are not. Other studies, which focused on natural experiments generated by political factors in the origin country (Card, 1990; Hunt, 1992; Carrington and de Lima, 1996), also found surprisingly little effects of migration.

The cross-market approach has recently been criticized by Borjas, Freeeman and Katz (1996). They argue that that an increase in labor supply in a certain city due to immigration can be diffused across the economy by intercity trade, movements of capital or by outflows of natives. Acknowledging this problem, a recent paper by Card (2001) assumes that immigrants and natives are perfect substitutes within occupations and cities. Under this assumption, he does find that occupation-specific wages and employment rates are systematically lower in cities with higher relative supplies of workers in a given occupation. Similarly, Borjas (2003) uses only variation in the human capital mix (determined by schooling and experience) of immigrants to study the effect of immigration on different groups of natives; he finds that, within groups, immigrants did have an adverse effect on wages and employment opportunities of natives. Angrist and Kugler (2003) focus on the correlation between institutions (such as employment protection, wage rigidities etc.) and the displacement effects of immigration across European countries. In contrast to previous studies, they do find that reduced flexibility may lead to a larger adverse effect of immigrants on natives' employment. Our paper supports this recent trend and suggests that the effects of immigration may be larger than what previously believed.

The remainder of the paper is organized as follows: the next section gives a brief account of the absorption of FSU immigrants in the Israeli labor market, and 
presents some preliminary evidence on the short and long run responses of wages and employment of natives. In Section 3 we present estimates on the effects of immigration on native outcomes assuming that the effect is homogeneous over time. In Section 4 we present and estimate the dynamic model and its outcomes. Section 5 concludes.

\section{Background and Data}

\section{Mass Migration to Israel}

From late 1989 until 2001, over a million of immigrants from the FSU arrived in Israel, increasing its population and labor force by extraordinary rates. At the peak of this wave during 1990 and 1991, over 330 thousand FSU Jews immigrated to Israel, increasing Israel's potential labor force by 8 percent and its population by 15

percent (see Figures 1a, $1 \mathrm{~b}^{2}$ ). The most notable characteristic of these immigrants is their high level of education. Table 1 presents the educational distribution of male and female natives and immigrants by year of arrival. Throughout the paper, we use the term "natives" to describe the population resident in Israel prior to January 1989. This includes both Israel-born and foreign-born individuals. Over 69 percent of all FSU male and female immigrants had at least some college education and over 40 percent were college graduates. The share of college-educated natives, on the other hand, is only about 35 percent, and only 22 percent of natives are college graduates. Table 1 also reveals that immigrants who arrived in the early wave were, on the average, more educated than those who arrived in the later wave.

In Table 2 we present the one-digit occupational distribution of natives and immigrants in two sub-periods, 1989-1993 and 1994-1999. The table shows that male immigrants are more concentrated than natives at both ends of the occupational ladder, while female immigrants are especially concentrated in the bottom. The distribution of natives is almost unchanged between the two periods. At a first glance, 
there is no evidence that immigrants substantially affected the occupational distribution of natives. This is important for our empirical analysis because it lends credibility to our assumption that natives' ability to move between segments of the labor market defined by occupation is limited. ${ }^{3}$ Therefore, our results are not likely to be contaminated by native flows across skill groups. As for the distribution of immigrants, it is worthwhile to note that in the early period (1989-1993) they were more likely to be employed in unskilled occupations, probably reflecting the fact that the size of the initial wave was so large that for many immigrants it was difficult to find a job suitable to their skills.

In contrast to earlier waves of immigrants to Israel during the $50 \mathrm{~s}$ and the $60 \mathrm{~s}$, FSU immigrants who arrived in the 90's could choose where to live right after arrival. Table 3 presents the residential distribution of immigrants and natives. The absolute majority of natives live in cities and metropolitan areas. The residential distribution of immigrants is quite similar to that of natives except that they seem to prefer the South to the North. Moreover, in the second sub-period (1994-1999) immigrants are substantially more concentrated in the south than immigrants who arrived at the beginning of the 1990s. Once again, the residential distribution of natives seems relatively fixed.

We now turn to the analysis of Israeli natives' labor market outcomes during the 1990s. Figure 2 shows the evolution of male and female real hourly wages between 1987 and 1999, where the scale is 100 in 1987 for each gender. We see that for both males and females real wages fell substantially at the time the migration wave began. Female real wages returned to their 1989 level only in 1994, and after dipping in 1995, they continued to grow more or less steadily throughout the second part of the

\footnotetext{
${ }^{2}$ The figures present the flow (1a) and the stock (1b) of immigrants at the ages of 25-64 as a percentage of the total population in this age group (Jews and non-Jews).

${ }^{3}$ In previous work (Cohen-Goldner and Paserman, 2004), we did not find any evidence that higher immigrant concentration in a given occupation affected the occupational choices of young native workers.
} 
decade. On the other hand, male wages were slower to recover, and only in 1996 did they return to their 1989 level for more than two consecutive years.

In Figure 3 we present the evolution of male and female employment to population rates (again the scale is 100 for each gender in 1987). Here it seems more difficult disentangle any potential effect due to immigration from cyclical and secular trends. The male employment rate was relatively stable throughout the first half of the decade, apart from cyclical movements, and has been falling steadily since 1995. On the other hand, the female employment rate is characterized by a secular upward trend.

The time-series evidence gives some preliminary sense that wages did initially react to the migration wave, and recovered later in the decade, while the picture for employment is less clear. We now turn to analyze whether there is a cross-sectional correlation between the concentration of immigrants in a sector and the change in wages or employment in the short and long run. For each two-digit occupation cell, we calculate the average log hourly wage of natives in every year, and the ratio of immigrants who arrived between 1989-1991 in the cell to the size of the cell in 1989. Holding constant the size of the cell in 1989 ensures that what we pick up is really just the variation in the number of immigrants in a cell (the numerator), not contaminated by native flows across labor market segments.

Figures 4 and 5 plot the change in log hourly wages against the fraction of 1989-1991 immigrants in two-digit occupation cells for males and females, respectively. The left-hand panel in the figures presents changes between 1989 and 1994 (the short-run change), while the right-hand panel presents changes between 1989 and 1999 (the long-run change). The overlaid regression line is obtained by weighted OLS, where each cell's weight is its average size. Note that the regression coefficient represents the percentage change in wages associated with a 100 percent change (i.e., a doubling) in the fraction of immigrants, and can therefore be interpreted as an elasticity. For both males and females, we find that the short run change in log hourly wages exhibits a strongly negative and statistically significant 
correlation with immigrant penetration at the two-digit occupation level. The regression coefficient places the unadjusted short-run factor price elasticity at around 0.55, a substantially larger number than what had been previously found in the literature. On the other hand, the long run elasticity is between 0.18 and 0.44 , and insignificantly different from zero for both males and females.

Figures 6 and 7 plot the change in employment rates, in the short run and the long run, against the fraction of 1989-1991 immigrants in two-digit occupation cells. For males, there seems to be a very tenuous relationship between the two variables, independently of the time horizon. For females, the pattern is more similar to that found for wages: employment is negatively correlated with immigrant concentration in the short run, but the long run correlation is essentially zero.

While these are very raw estimates, they illustrate clearly the importance of distinguishing between the short and long run effects of immigration, and they provide some preliminary support for the notion that any adverse effects of immigration are more likely to manifest themselves in the short run, before the labor market has had time to adjust.

In the next sections, we investigate further whether the contrast between the short and long run effects of immigration is robust to the use of individual level data, to the inclusion of additional controls for macroeconomic conditions, individual characteristics, to different segmentations of the labor market, and to alternative structures of the error term.

\section{$\underline{\text { Data }}$}

We use micro data from the Israeli Labor Force Survey (LFS) and the Income Survey (IS) of 1989-1999. The LFS is a rotating panel, where each household is interviewed for two consecutive quarters, followed by a break of two quarters, and is interviewed again for two consecutive quarters. In the fourth interview, a sub-sample of the respondents is asked questions about their income, and this information makes up the Income Survey. In our employment regressions we use data from the LFS, 
while the Income Survey provides the basis for our wage regressions. The male sample includes men between 25 and 65, the female sample includes women between 25 and $60 .{ }^{4}$ We do include non-Jews in our sample, but we exclude ultra-orthodox Jews, people who reported more than 30 years of schooling, and immigrants whose age at arrival was under $25 .{ }^{5}$ Since most of our segmentations are based on workers' occupational category, we also drop from the sample workers who did not report a previous occupation. This excludes from the sample workers who are unemployed for more than a year and individuals out of the labor force who did not work in the calendar year prior to the survey date. Summary statistics for the demographic characteristics in the LFS and IS sample are given in Table 4.

\section{Methodology}

$\underline{\text { Static Model }}$

We begin by specifying a conventional model for the impact of immigration on native labor market outcomes. Our estimating equation is

$$
y_{i j t}=\beta_{0}+\beta_{1} I M M_{j t}+\beta_{2} Z_{j t}+\beta_{3} X_{i j t}+\alpha_{j}+\delta_{t}+\varepsilon_{i j t},
$$

where $y_{i j t}$ is the outcome variable of interest for individual $i$ in labor market segment $j$ observed in calendar quarter $t$. In the wage regressions $y_{i j t}$ is the log hourly wage, while in the employment regressions it is a dummy indicator for whether the individual is employed. $I M M_{j t}$ is the ratio of immigrants (both men and women) in segment $j$ at time $t$ to the size of cell $j$ in $1989, Z_{j t}$ and $X_{i j t}$ are vectors of observable macro and individual characteristics, $\alpha_{j}$ is a segment specific fixed effect, $\delta_{t}$ is a calendar quarter fixed effect, and $\varepsilon_{i j t}$ is the error term. All regressions adjust standard errors for clustering at the cell-calendar quarter level. The underlying assumption in equation (1) is that all immigrants have the same effect on the dependent variable, regardless of their time of arrival in Israel. Note that the all the time-series variation in

\footnotetext{
${ }^{4}$ These were the mandatory retirement ages for men and women during the sample period.

${ }^{5}$ Immigrants who arrived prior to age 25 may have acquired part of their education in Israel, making their transition to the labor market more similar to that of young natives than to that of immigrants.
} 
the immigrant ratio in a given cell comes from the number of immigrants, since the denominator (the number of natives) is fixed.

Equation (1) can be estimated both without and with segment-specific fixed effects. In the latter case, identification is achieved from the variation across segments and over time in the fraction of immigrants. Note that we implicitly assume that there are no time-varying segment-specific effects. In other words, while we allow immigrant concentration to be potentially correlated with the unobserved overall level of wages or employment in a segment, we rule out the possibility that it is correlated with unobserved changes in wages or employment. The analysis of the dynamic model that follows relaxes this assumption.

The vector $Z_{j t}$ represents a set of controls primarily for labor demand shocks for workers in segment $j$ at time $t$. In particular, $Z_{j t}$ includes the total number of workers in cell $j$ at time $t$, and an index for labor demand for workers in the cell. Specifically, the labor demand index for segment $j$ in year $s,{ }^{6} L D_{j s}$ is constructed as follows:

$$
L D_{j s}=\sum_{k} p_{j k} Y_{k s}
$$

where $Y_{k s}$ is the real level of industrial production in (one-digit) industry $k$ in year $s$, and $p_{j k}$ is the 1989-1999 proportion of workers in segment $j$ who are employed in industry $k$. In other words, the labor demand index for cell $j$ is a weighted average of industrial production in year $s$, where the weights are given by the industry shares of employment of cell $j$ workers. To illustrate, if a large share of engineers is employed in manufacturing, and the GDP share of manufacturing decreases, this will lower the demand for engineers.

The vector $X_{i j t}$ represents a set of individual demographic characteristics of worker $i$ in cell $j$ at time $t$, and it includes years of schooling, potential experience (age - years of schooling - 6), and potential experience squared; a marital status dummy (1 
if married, zero otherwise) and the number of children aged 0-4, 5-14, and 15-17; a dummy for whether the individual is foreign born ( 1 for Israeli born) and the number of years since immigration; a set of ethnic origin variables - Jews of European/American origin (Ashkenazi), Jews of Asian/African origin (Sephardi), and non-Jews; ${ }^{7}$ and a dummy for whether the individual is employed in the public sector. In all regressions we include a full set of calendar quarter dummies, to capture unobserved macroeconomic conditions.

We adopt five different segmentations of the labor market. As in Friedberg (2001), we start by defining a closed labor market segment as a two digit occupation cell. In addition, we also construct cells defined by one-digit occupation interacted in turn with district of residence, schooling, and one-digit industry and, following Borjas (2003), cells defined by schooling interacted with potential experience. ${ }^{8}$

Table 5 presents the overall average in the fraction of immigrants according to the five different labor market segmentations.

\section{Dynamic Model}

We extend now equation (1) to allow for immigrants with different levels of tenure in Israel to have a different impact on native outcomes. Specifically, let $I M M_{j s t}$ be the ratio of immigrants with $s$ years of tenure Israel in cell $j$ at time $t$ to the size of cell $j$ in 1989. Then the estimating equation becomes

$$
\begin{aligned}
y_{i j t}= & \beta_{0}+\gamma_{0} I M M_{j 0 t}+\gamma_{1} I M M_{j 1 t}+\ldots+\gamma_{10} I M M_{j, 10, t} \\
& +\beta_{2} Z_{j t}+\beta_{3} X_{i j t}+\alpha_{j}+\delta_{t}+\varepsilon_{i j t} .
\end{aligned}
$$

\footnotetext{
${ }^{6}$ The labor demand index varies only by year and labor market segment, since data on 1-digit industry production is available only at the yearly level. Clearly, this same index will be assigned to all observations within a calendar year.

${ }^{7}$ Ethnic origin is determined by the country of birth of the respondent, or, if the respondent was born in Israel, by country of birth of the respondent's father. The omitted category is third-generation Israeli Jews.

${ }^{8} \mathrm{We}$ assume that experience acquired abroad is equivalent to experience acquired in Israel.
} 
We are particularly interested in the pattern of the $\gamma$ coefficients. This pattern depends on the degree of substitutability between immigrants and natives in the short run, and on the speed of adjustment of local factors of production to the migration wave.

To illustrate this, consider a simple production function with two factors, labor and capital. ${ }^{9}$ A high degree of substitutability between immigrants and natives implies that the initial impact of migration on native outcomes should be substantial, as the stock of capital is fixed in the short run. If capital and labor are non-rival in production, the initial migration wave will raise the marginal productivity of capital, so that in the medium and long run the demand for capital increases. The rightward shift in the demand for capital raises in turn the marginal productivity of labor, and therefore labor demand increases as well. As a result, the initial adverse impact of migration on native wages and employment will be mitigated in the long run. ${ }^{10}$ If this is the case, we expect the short-run $\gamma$ 's to be significant and negative, while the long run $\gamma$ 's to be smaller.

An alternative possibility is that in the short run immigrants are relatively poor substitutes for natives, but the degree of substitutability increases over time as immigrants gradually acquire local labor market skills. Depending on the speed of adjustment of capital, we could have a scenario in which the initial impact of immigration is negligible (or maybe even positive if immigrants and natives are complements, and immigration pushes up the marginal productivity of Israeli workers), but the effect becomes more negative over time. In this case, the short run $\gamma$ 's are zero or maybe even positive, while the adverse impact of immigration manifests itself in the long-run $\gamma$ 's.

\footnotetext{
${ }^{9}$ We can think of the labor index in the production function as a composite aggregate of native and immigrant workers.

${ }^{10}$ In a two sector open economy, if the total supply of capital is fixed, an increase in the amount of one factor of production will only cause a reallocation of production factors across sectors, depending on the factor intensities of each sector, and will not affect factor prices in the long run. This is the Rybczinsky theorem from international trade theory. See Gandal, Hanson and Slaughter (2004) for an empirical analysis of the Israeli case.
} 
Since we have only eleven years of data, it might be difficult to estimate precisely the coefficients on the long-run $\gamma$ 's. For example, $\gamma_{10}$ is identified only from the 1999 wave of the LFS, and there might not be enough observations in each cell to obtain a satisfactory estimate of this parameter. Therefore, we adopt a linear functional form for the structure of the $\gamma$ 's. Specifically, we assume that

$$
\gamma_{s}=\lambda_{0}+\lambda_{1} s
$$

Substituting for $\gamma_{\mathrm{s}}$ in equation (2), we obtain:

$$
\begin{aligned}
y_{i j t} & =\beta_{0}+\lambda_{0} \sum_{s} I M M_{j s t}+\lambda_{1} \sum_{s} s \times I M M_{j s t}+\beta_{1} Z_{j t}+\beta_{2} X_{i j t}+\alpha_{j}+\delta_{t}+\varepsilon_{i j t} \\
& =\beta_{0}+\lambda_{0} I M M_{j t}+\lambda_{1} I \tilde{M} M_{j t}+\beta_{1} Z_{j t}+\beta_{2} X_{i j t}+\alpha_{j}+\delta_{t}+\varepsilon_{i j t},
\end{aligned}
$$

where $I M M_{j t}$ is the ratio of total stock of immigrants in cell $j$ at time $t$ to the size of the

cell in 1989 (defined exactly as in equation (1) in the static model), and $I \tilde{M} M_{j t}$ is the weighted sum of ratios of immigrant-years in cell $j$ at time $t$ to the size of the cell in 1989. In this specification, the parameters $\lambda_{0}$ and $\lambda_{1}$ have a very straightforward interpretation: $\lambda_{0}$, which is equivalent to $\gamma_{0}$ in (2), measures the immediate impact of immigration on labor market outcomes. If immigrants upon arrival are close substitutes to natives, we expect $\lambda_{0}$ to be negative, while it should be zero or even positive if the degree of substitutability is low. The second coefficient, $\lambda_{1}$, measures how the impact of immigration changes over time. We expect $\lambda_{1}$ to be positive if the adverse impact of immigration becomes smaller over time, whereas it should be negative if the native labor market is negatively affected only some years after the initial arrival of immigrants. A simple hypothesis test for the null of $\lambda_{1}$ equal to zero essentially tests whether the impact of immigration is homogeneous over time.

\section{Identification Issues}

Like in the static model, it is important to make sure that the effect we identify in the dynamic model is not simply due to the selection of immigrants across labor 
market segments. To illustrate the problem, consider the following simple two period example: the labor market consists of two segments, a low wage and a high wage segment. The wage in each segment is fixed and is not affected by immigration. In each period, a wave of immigrants arrives and is employed in the low wage segment. After one period in the host country, all immigrants move to the high wage segment of the labor market. Therefore, all recent immigrants are concentrated in the low wage segment, and all veteran immigrants are concentrated in the high wage segment. As a result, wages are negatively correlated with the concentration of recent immigrants, and positively correlated with the concentration of veteran immigrants. Despite the fact that immigration has no effect on wages, we could erroneously conclude that the initial effect is negative, and then disappears in the long run. In this simplified example, controlling for segment specific effects would prevent us from reaching the wrong conclusion.

However, controlling for segment specific fixed effects is not enough if the segment specific wages are not really fixed. Assume for example that wage growth in the high wage segment is faster than in the low wage segment. Then the deviation in wages from the segment mean is positively correlated with deviation in the fraction of veteran immigrants from the segment mean, while it is negatively correlated with the deviation in the fraction of recent immigrants from the segment mean. Hence, even controlling for fixed effects would yield a spurious conclusion that the impact of immigration changes over time. To alleviate this concern, we test the robustness of the estimates to the inclusion of more complex dynamic structures of the segment specific effect.

An additional threat to identification would arise if the impact of immigration is indeed the same, regardless of immigrant tenure in Israel, but different cohorts of immigrants have different effects on native outcomes. In a sense, this identification problem is similar to the one that arises in the estimation of the immigrant wagetenure profile. In a single cross-section, it is impossible to identify separately tenure effects from cohort effects. With repeated cross-sections, as in our data, identification 
becomes possible, but one must impose additional restrictions. To see this, let $I M M_{j s t}$ be the fraction of immigrants with $s$ years of tenure in Israel, and let $I M M_{j c t}$ be the fraction of immigrants who arrived in cohort (year) $c$. A general model would allow a different effect for immigrants of any possible combination of cohort and tenure. However, this model is clearly not identified since in a given cell, the sum of the number immigrants with different tenure in Israel is identical to the sum of the number of immigrants from different cohorts. ${ }^{11}$ The same identification problem arises even if we impose a linear structure on the pattern of coefficients. To get around the identification problem, we must assume that at least one cohort or tenure coefficient is equal to zero. In practice, we will assume that we can characterize two cohorts of immigrants: those that arrived between 1989 and 1992 (these immigrants essentially fled the Soviet Union in haste, fearing that the country would fall into chaos, and can be described as "refugees"); and those that arrived in 1993 and later, which share more of the features of economic migrants. The identifying assumption then is that the impact of the first cohort is zero, and we will test whether adding cohort effects changes our estimates in equation (3).

\section{Results}

$\underline{\text { Wages }}$

The first two columns of Table 6 present the estimation results for the effect of immigration on natives' log hourly wage, assuming that the effect of immigration is homogeneous over time. We present results for both males and females, with and without fixed effects, and for the five possible segmentations of the labor market. ${ }^{12}$ We first examine the specification without fixed effects in the first column of the table. The results here are sensitive to the choice of labor market segmentation. When

\footnotetext{
11 Mathematically, $\sum_{s} I M M_{j s t}=\sum_{c} I M M_{j c t}$. Therefore, we have a perfect multicollinearity problem.

${ }^{12}$ The regressions are run separately for men and women, but the key explanatory variable is calculated as the ratio of total immigrants (both men and women) to native employment in a labor market cell in 1989.
} 
the segmentation is based on occupational category, we generally find a strong negative correlation between immigrant concentration and native wages. On the other hand, the fraction of immigrants in a schooling-experience cell is strongly positively correlated with native wages. There is a simple explanation for this finding. Immigrants from the FSU are substantially more educated than natives (see Table 1); however, upon arrival, they cluster in low skill jobs that pay low wages (Eckstein and Weiss, 2002; Weiss, Sauer and Gotlibovski, 2003). Therefore, at the cross-sectional level, we expect to find a strong negative correlation between the fraction of immigrants and natives' wages at the occupational level, but a positive correlation between immigrants and natives' wages when we segment the labor market by schooling and experience.

Part of the correlation may rise from the selectivity of immigrants across labor market cells. Hence, we should not attach any causal interpretation to the estimates stemming from the no-fixed effects specification; however, we believe that it is important to report them in order to better understand the nature of the selection of immigrants across labor market segments.

The fixed effects estimates in the second column of the table reinforce the above interpretation. For all specifications and for both sexes, we find that the coefficient estimate in the fixed effect specification is substantially smaller (in absolute value) than the coefficient estimate when fixed effects are not included. For males, the coefficient is negative and statistically significant when we segment the labor market by district of residence and occupation, it is essentially zero in the other occupation-based segmentations, and it is still positive and significant in the schooling-experience segmentation. For females, the coefficient is negative and statistically significant in all the occupation-based segmentations, and it is positive and statistically significant in the schooling-experience segmentation. We conjecture that this latter result is due to the fact that human capital accumulated abroad is not entirely transferable to the host economy (Friedberg, 1999; Eckstein and Weiss, 2003; Kugler and Sauer, 2003), especially in the short run, and hence the segmentation 
based on schooling and experience does not accurately reflect the competition from immigrants faced by native workers.

The estimates of the dynamic model are presented in specifications 3 and 4 . Once again, to illustrate the nature of the selection process, we present results from specifications without segment fixed effects (specification 3) and with segment fixed effects (specification 4). When fixed effects are omitted, we find a pattern similar to that of the static model: in the occupation-based segmentations, there is a very strong short run negative correlation between immigration and native wages, with the sign of the effect reverting in the long run. The pattern of signs is reversed in the schoolingexperience segmentation. As discussed above, this is likely to be due to the selection of immigrants upon arrival in low wage segments, and their subsequent move up the occupational ladder. In fact, when segment fixed effects are included, the estimate for both $\lambda_{0}$ and $\lambda_{1}$ fall substantially. However, in three of the five segmentations for males, and in four of the five segmentations for females, we find that $\lambda_{0}$, the estimate for the immediate effect of immigration on wages, is negative and statistically significant. The estimate of $\lambda_{I}$ is positive and statistically significant for both males and females in the segmentation based on two-digit occupational cells, it is positive and significant in one additional specification for both sexes, and it generally has the "right" sign in all the occupational-based segmentations.

The pattern of signs in the schooling-experience segmentation is reversed, even though the estimates are not statistically different from zero at conventional significance levels. This could be because, as explained previously, immigrants with a given level of schooling and experience are not necessarily substitutes to natives with the same attributes. In fact, the positive short-run and negative long-run coefficients are not entirely surprising in this specification, since it is exactly when we segment the labor market by schooling and experience that we expect the degree of substitutability between immigrants and natives to increase over time.

It is worthwhile to compare these results to those of the static model: assuming that the effect of immigration is constant over time and using the two-digit occupation 
segmentation, we would have concluded that the elasticity of native male wages with respect to immigration is zero, and that of females is -0.11 . However, when we allow the effect to differ depending on immigrants' tenure in Israel, our conclusion is dramatically altered. The short run elasticity of wages is -0.20 for males and -0.28 for females, and it takes between 5 and 7 years for occupation-level wages to return to their pre-immigration level.

\section{$\underline{\text { Employment }}$}

The first two columns of Table 7 present the estimates of the static model for employment rates. For males, the pattern is similar to that found for wages. There is a negative cross-sectional correlation between employment and immigrant penetration, but this relationship disappears once we control for segment specific effects. Interestingly, we do not find any evidence of a positive correlation in the schoolingexperience segmentation. For females, we observe a negative cross-sectional correlation in the occupation-based segmentations, and a positive correlation in the schooling-experience segmentation. All of the correlations switch signs when we include fixed effects, although only the coefficient in the 2-digit occupation segmentation is statistically significant.

In the remaining columns of Table 7 we present the estimates of the dynamic model for employment rates. In the specification without fixed effects, we find the familiar pattern of coefficients, driven by selection. The fixed effects estimates, on the other hand, yield mixed results: we find a short-run negative correlation for males, which diminishes over time, in the schooling-experience segmentation; and a positive short-run correlation for females. All the other coefficients are statistically insignificant, and it is difficult to detect any consistent pattern in the signs of the estimates. Overall, it seems difficult to draw any definite conclusions on the effect of immigration on natives' employment rates. This could be due to several factors. First, our sample is based essentially only on workers in the labor force: it is possible that immigration operates mainly on the labor force status margin. Second, there seem to 
be important secular trends in both male and female labor supply (see Figure 3), which may make it difficult to identify any effects due to immigration. Finally, if the labor supply curve is inelastic, we would indeed not expect immigration to have any effect on natives' employment.

\section{Robustness Checks}

Since there appears to be essentially no effect of immigration on employment, neither in short nor in the long run, we report robustness checks for the effect of immigration on native wages alone. ${ }^{13}$ In addition, we concentrate only on the three labor market segmentations (by two-digit occupation, district of residence-occupation, and industry-occupation) in which the dynamic nature of the impact appears to be strongest. The results are presented in Table 8 .

The first two columns of the table adjust standard errors for potential serial correlation in the error term. The standard errors reported in Table 6 are correct if there is no serial correlation between the residuals in a particular labor market cell (formally, $\varepsilon_{i j t}$ and $\varepsilon_{i j s}$ in equation (3) must be uncorrelated for any two periods $s$ and $t$ ). As shown by Bertrand et al. (2004), serial correlation within clusters in differences in differences analysis can lead to serious biases in estimated standard errors, especially so if the explanatory variable of interest is highly persistent. To address this concern, Bertrand et al. suggest estimating the equation with clustering at the cell level, rather than at the cell-time unit level. Column (1) in Tables 8 replicates column (4) in Table 6, but presents autocorrelation-robust standard errors. For males, the precision of the estimates is slightly hurt in the district of residence-occupation and in the industryoccupation segmentations, but the coefficient for the immediate impact remains significant. For females, the largest increase in standard errors occurs in the two digit occupation segmentation, but the coefficients remain significant.

\footnotetext{
${ }^{13}$ Similar robustness checks for employment regressions yielded essentially the same results as in Table 7.
} 
In the next two columns of the table [specification (2)], we test whether our results are driven by the fact that different cohorts of immigrants affect the labor market differently, as discussed in Section 3. The inclusion of a cohort of immigration dummy has little effect on either the magnitude or the significance level of the coefficients.

In specification (3) we test for robustness of our estimates to a more flexible specification of the error term structure. Specifically, we allow the segment effects to be time-varying, but we restrict the dynamics to follow a linear trend. ${ }^{14}$ The regression equation is estimated with a full set of segment-specific fixed effects, and a full set of segment-specific effects interacted with a linear time trend. In other words, we attempt to identify any effects of immigration from the deviations in wages and immigrant concentration from their segment specific trends. For both males and females we find that the short-run effect of immigration is smaller in absolute value once we control for a segment specific trend. For males, two of the three significant coefficients in the benchmark case remain statistically significant. The short-run coefficient in the two-digit occupation segmentation is halved in size and becomes insignificant. For females, all the coefficients become insignificant at the 5 percent level, although the pattern of signs is preserved, and all the t-statistics are above one. We should not be too surprised by the loss in precision of our estimates, since the inclusion of so many segment specific effects may swamp out much of the useful variation that can aid us in identification.

In specification (4) we go one step further, and relax the linear trend assumption for the dynamics of the unobserved effect. In its place, we assume that the segment specific effect can vary freely over time, but the dynamics are constant within broad groupings of segments. Specifically, suppose that the index $j_{g_{1} g_{2}}$ denotes that segment $j$ belongs to broad groupings $g_{1}$ and $g_{2}$. For example, if the segmentation is based on district of residence and one-digit occupational category, then the labor

\footnotetext{
${ }^{14}$ Formally, in equation (3) we substitute $\alpha_{j}$ with $\alpha_{j t}=\eta_{j}+\zeta_{j} \times t$.
} 
market segment for professional workers in the Tel Aviv district belongs to the aggregate grouping of all professional workers $\left(g_{l}\right)$, and to the aggregate grouping of all Tel Aviv residents $\left(g_{2}\right)$. Then, the individual effect for segment $j_{g_{1} g_{2}}$ at time $t$ is $\alpha_{j_{g_{182} t}=\eta_{j}}+\theta_{g_{1}} \delta_{t}+\theta_{g_{2}} \delta_{t}$. In our example, this means adding to regression (4) in Table 6 a full set of district of residence dummies interacted with a full set of year dummies, and a full set of one-digit occupation dummies interacted with a full set of year dummies. In this specification, identification is achieved off the deviations in segment-specific immigrant concentration and wages from their overall mean in the sample period (because of the inclusion of the cell fixed effects) and from the period $t$ mean in broad groupings of segments.

For males we find that the short-run effect of immigration disappears in the residence-occupation segmentation, but is unaffected in the other two segmentations. For females, the effect maintains its sign and significance level only in the two-digit occupation segmentation. It is difficult to interpret these results: on one hand, it's possible that part of the estimated coefficient in the fixed effects specification was capturing the concentration of newly arrived immigrants in sectors with temporarily low wages; on the other hand, it could be that the more complex dynamic structure of the unobserved component swamps out much of the useful variation that is necessary to estimate the effect precisely.

In Table 9 we check whether the results are robust to a more flexible specification of the dynamic impact of immigration on native wages. In particular, we specify a piecewise-constant function for the $\gamma$ s in equation (1):

$$
\gamma_{s}=\mu_{0} \cdot 1(s=0)+\mu_{1} \cdot 1(1 \leq s \leq 3)+\mu_{2} \cdot 1(4 \leq s \leq 6)+\mu_{3} \cdot 1(7 \leq s \leq 10) .
$$

The estimating equation then becomes

$$
\begin{aligned}
y_{i j t}= & \beta_{0}+\mu_{0} I M M_{j 0 t}+\mu_{1} \sum_{s=1}^{3} I M M_{j s t}+\mu_{2} \sum_{s=4}^{6} I M M_{j s t}+\mu_{3} \sum_{s=7}^{10} I M M_{j s t}+ \\
& +\beta_{1} Z_{j t}+\beta_{2} X_{i j t}+\alpha_{j}+\delta_{t}+\varepsilon_{i j t} .
\end{aligned}
$$

This specification allows us to identify more accurately the dynamic structure of the immigration impact. We estimate equation (4) both with only cell fixed effects, and 
with a full set of cell effects interacted with a linear trend. In both specifications, we find that the adverse impact of immigration on native wages is concentrated one to three years after the immigrants' arrival. This effect is present for both males and females, and is statistically significant in nearly all segmentations. Controlling for a more complex dynamic structure of the error term has little effect on the estimates for males, while it reduces by about half those for females. The estimates imply that a 10 percent increase in the fraction of immigrants with one to three years of tenure in Israel reduces native wages by 1.1 to 3.2 percent for males, and by 0.4 to 5.1 percent for females. At all other time spans, the effect is essentially zero in all specifications. The fact that the effect is concentrated in the short run (though not in the very short run, at zero years of tenure), is consistent with the hypothesis that immigrants are substitutes for native workers, and that other factors of production adjust within one to three years after the immigrants' arrival, so that in the medium and long run the effect of immigration on native wages is essentially zero.

Overall, the results provide support for our general conclusion that the impact of immigration is largest upon the immigrants' arrival, and then diminishes over time, even though we cannot rule out completely that the results are driven by complex dynamics in the unobservable factors that affect wages and employment.

\section{Conclusion}

This paper studies the dynamic impact of the mass migration from the former Soviet Union on native Israelis' labor market outcomes. The key feature of our paper is allowing the impact of immigration to vary over time. Our results indicate that immigration did have a short-run adverse impact on wages, with the effect dying out after 5 to 7 years. However, we do not find any immediate nor delayed impact on employment. Our preferred estimates suggest that a 10 percent increase in the share of immigrants lowers natives' wages in the short run by 1.2 to 5.7 percent. These findings are consistent with the notion that within occupation oriented segments, immigrants are close substitutes to natives in the short run and depress natives' wages; 
however, as the labor market adjusts to the migration wave through offsetting flows of capital and other factors of production, the adverse effect is diffused in the medium and long run. These results are robust to the inclusion of cohort effects and to the selection of immigrants into low wage or low wage growth segments in the labor market.

We should be aware of the idiosyncratic characteristics of the Israeli case study, which may make our results difficult to extend to other countries. The Soviet migration wave represented a sudden large deviation of the immigration rate from its long-run steady-state level. In this setting, it is not surprising that the short-run impact of immigration was substantial, as other factors of production did not have time to adjust due to the unexpected nature of the shock. The dynamic response of the labor market to small fluctuations in the immigration rate from its steady-state, or to gradual increases in the immigration rate, should not necessarily resemble that found in our paper. Nevertheless, we view our methodological contribution as potentially important for understanding the economic impact of immigration in other contexts as well. We leave the investigation of this matter for future research. 


\section{References}

Altonji, Joseph G., and Card, David. "The Effects of Immigration on the Labor Market Outcomes of Less-Skilled Natives." In Immigration, Trade and Labor, edited by John M. Abowd, and Richard B. Freeman. Chicago: University of Chicago Press, 1991.

Angrist, Joshua D., and Kugler, Adriana D. "Protective or Counter-Productive? Labour Market Institutions and the Effect of Immigration on EU Natives." Economic Journal, June 2003, 113(488), pp. F302-31

Bauer, Thomas; Lofstrom, Magnus and Zimmermann, Klaus F. "Immigration Policy, Assimilation of Immigrants, and Natives' Sentiments Towards Immigrants: Evidence from 12 OECD Countries." Swedish Economic Policy Review, 7(2), Fall 2000, pp. 11-53.

Borjas, George J., Freeman, Richard B, and Katz, Lawrence. "Searching for the Effect of Immigration on the Labor Market”, American Economic Review, 86(2), May 1996, pp. 246-251.

Borjas, George J. "The Labor Demand Curve Is Downward Sloping: Reexamining the Impact of Immigration on the Labor Market." Quarterly Journal of Economics, November 2003, forthcoming.

Card, David. "The Impact of the Mariel Boatlift on the Miami Labor Market." Industrial and Labor Relations Review, 43(1), January 1990, pp. 245-257.

Card, David. "Immigrant Inflows, Native Outflows, and the Local Labor Market Impacts of Higher Immigration." Journal of Labor Economics, 19(1), January 2001, pp. 22-64.

Carrington, William J. and de Lima, Pedro J.F. “The Impact of 1970s Repatriates from Africa on the Portuguese Labor Market." Industrial and Labor Relations Review, 49(2), January 1996, pp. 330-347.

Cohen-Goldner, Sarit and Paserman, M. Daniele. "Mass Migration to Israel and Natives' Transitions from Employment." Mimeo., Bar-Ilan University and Hebrew University, May 2004.

Eckstein, Zvi and Weiss, Yoram., "The Integration of Immigrants from the Former Soviet Union in the Israeli Labor Market," in The Israeli Economy, 19851998: From Government Intervention to Market Economics, Essays in Memory of Prof. Michael Bruno, edited by Ben-Bassat, Avi. Cambridge: MIT Press, 2002. 
Eckstein, Zvi and Weiss, Yoram., "On the Wage Growth of Immigrants: Israel 1990-2000,” CEPR Discussion Paper 3770, 2003.

Friedberg, Rachel M. "You Can't Take It with You? Immigrant Assimilation and the Portability of Human Capital." Journal of Labor Economics, 18(2), April 2000, pp. 221-251.

Friedberg, Rachel M. "The Impact of Mass Migration on the Israeli Labor Market." Quarterly Journal of Economics, 116(4), November 2001, pp. 1373-1408.

Gandal, Neil; Hanson, Gordon H. and Slaughter, Matthew J. “Technology, Trade and Adjustment to Immigration in Israel.” European Economic Review, April 2004, 48(2), pp. 403-428.

Goldin, Claudia. "The Political Economy of Immigration Restriction in the United States, 1890-1921." In The Regulated Economy: A Historical Approach to Political Economy, edited by Claudia Goldin and G. Libecap. Chicago: University of Chicago Press, 1994.

Hunt, Jennifer. "The Impact of the 1962 Repatriates from Algeria on the French Labor Market." Industrial and Labor Relations Review, 45(?), April 1992, pp. 556572.

Kugler, Adriana D., and Sauer, Robert M. "Doctors Without Borders: The Returns to an Occupational License for Soviet Immigrant Physicians in Israel.” The Maurice Falk Institute for Economic Research in Israel, Discussion Paper 03.01, 2003.

LaLonde, Robert and Topel, Robert. "Labor Market Adjustments to Increased Immigration." In Immigration, Trade and Labor, edited by John M. Abowd, and Richard B. Freeman. Chicago: University of Chicago Press, 1991.

Pischke, Jorn-Steffen and Velling, Johannes. "Employment Effects of Immigration to Germany: An Analysis Based on Local Labor Markets." Review of Economics and Statistics, 79(4), November 1997, pp. 594-604.

Weiss, Yoram; Sauer, Robert M.; and Gotlibovski, Menachem. "Immigration, Search, and Loss of Skill.” Journal of Labor Economics, 21(3), July 2003, pp.557591. 


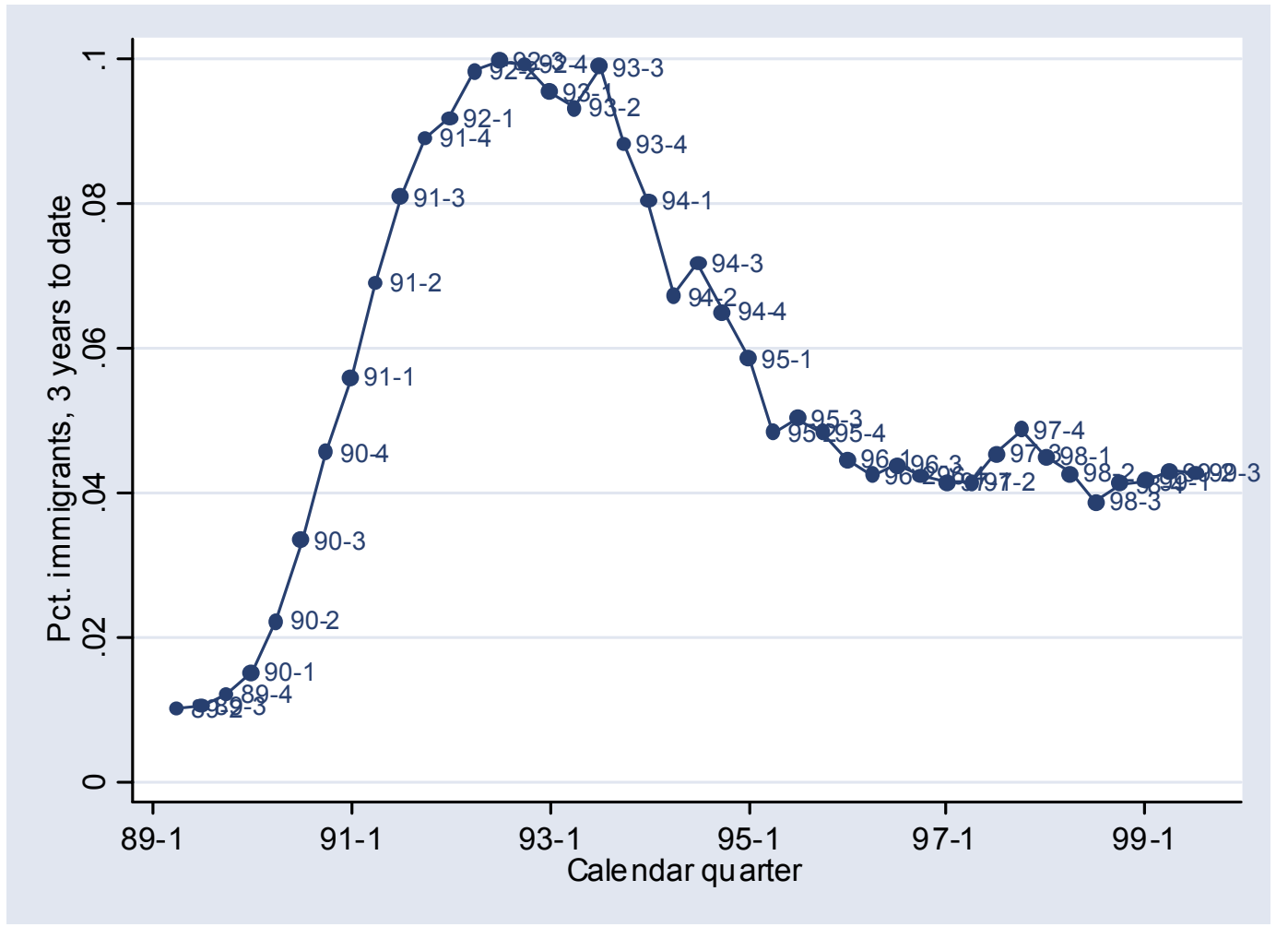

Figure 1a: Immigrant Flow, 1989-1999

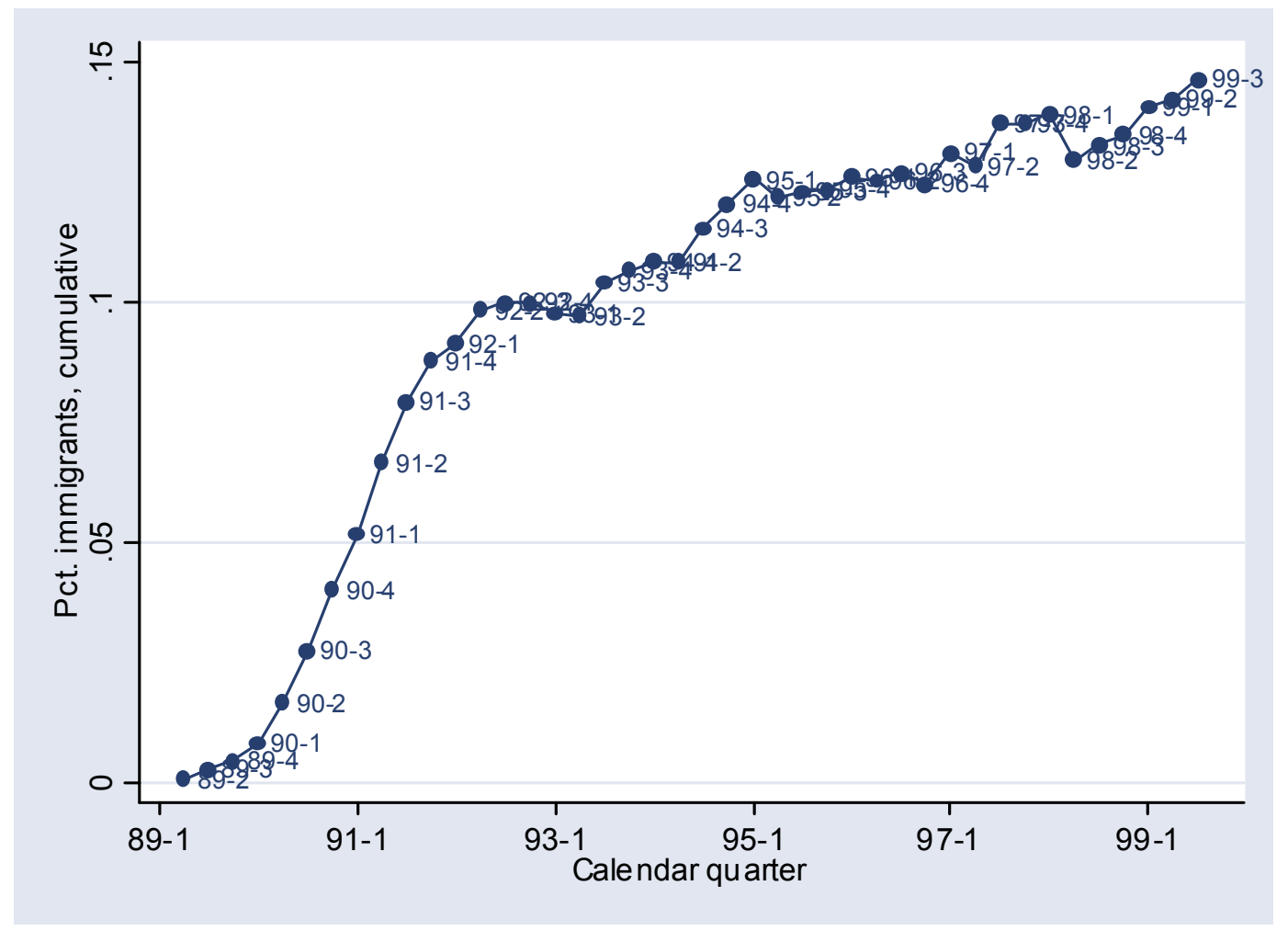

Figure 1b: Immigrant Stock, 1989-1999 


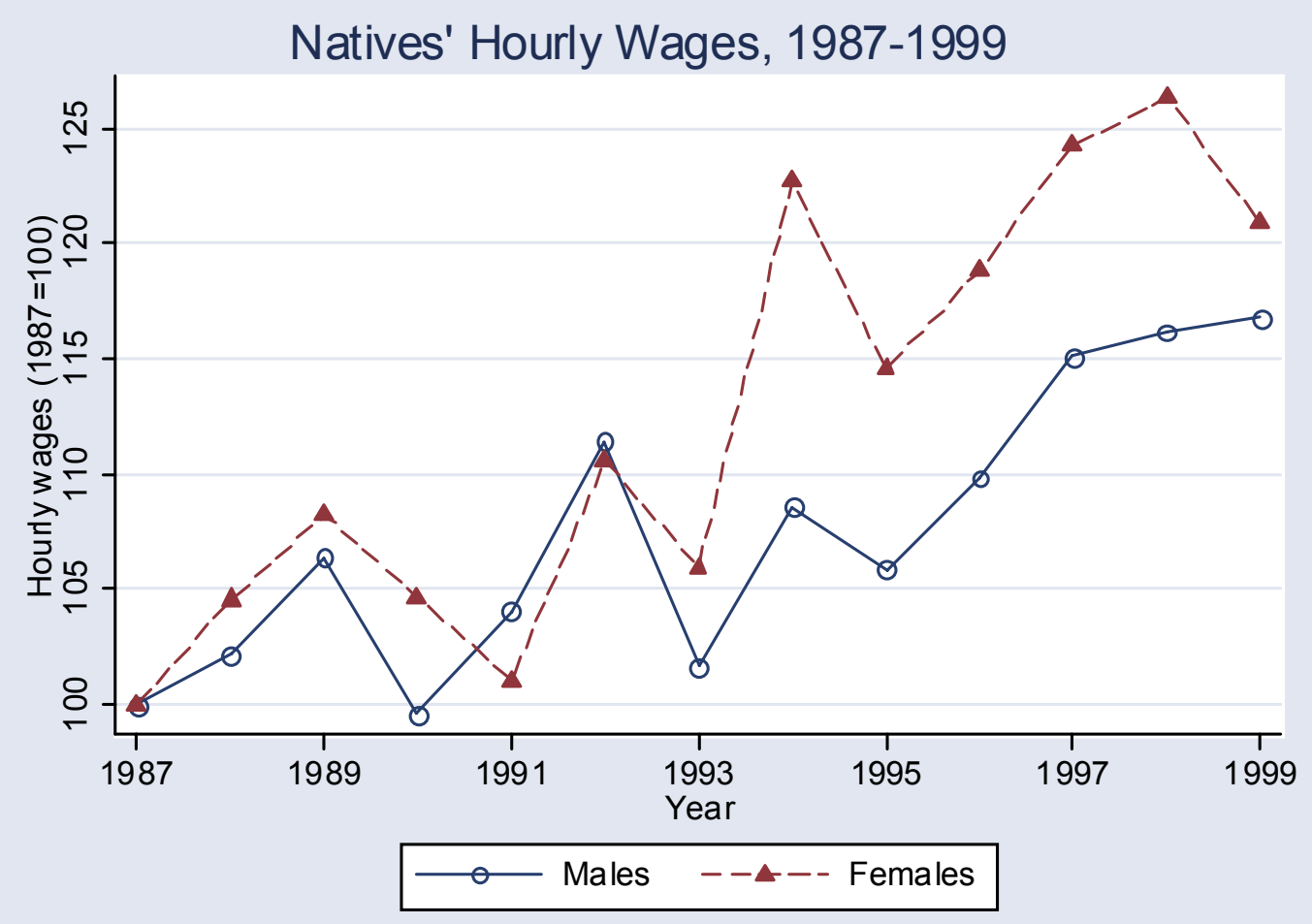

Figure 2: Natives' Hourly Wages, 1989-1999

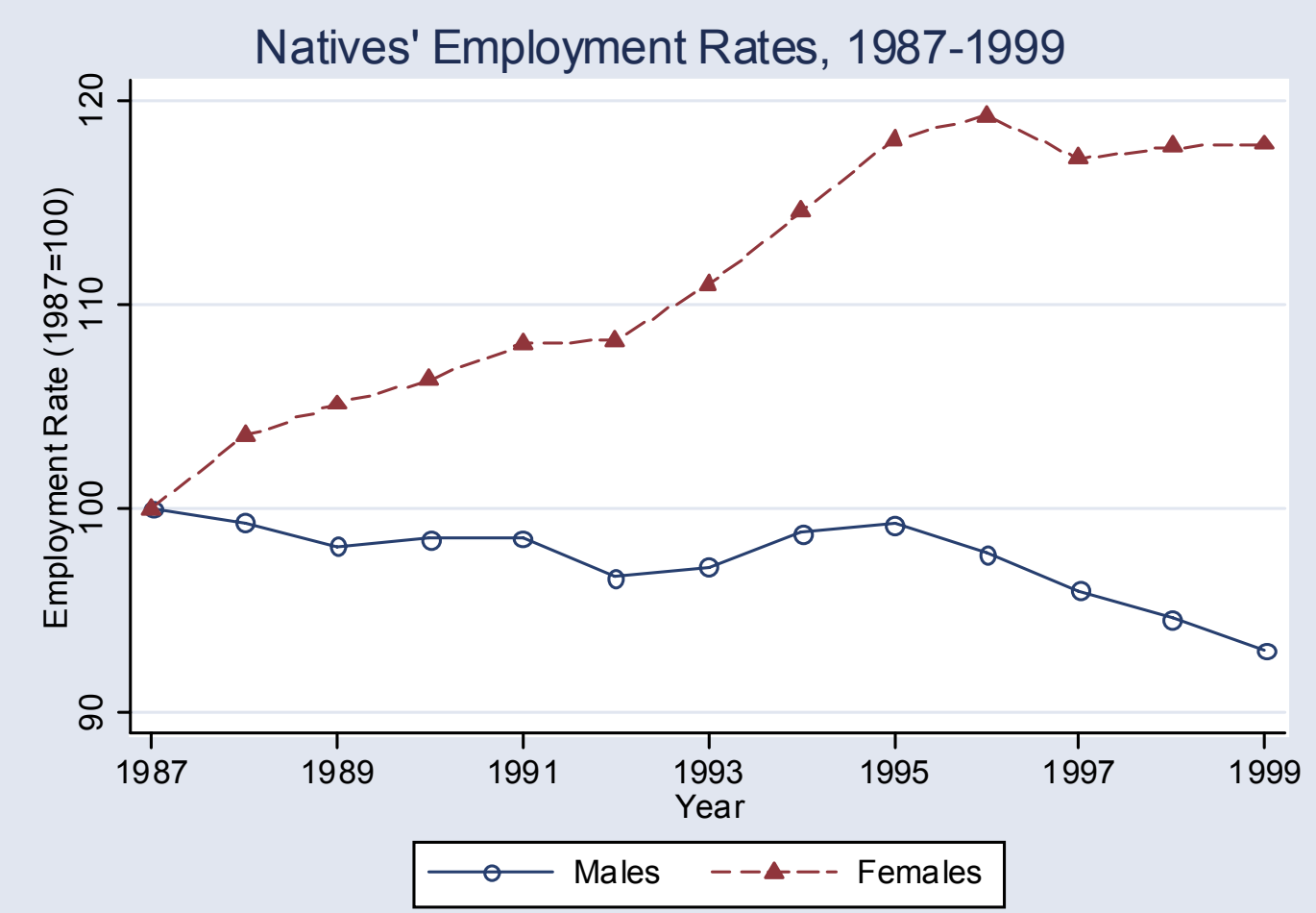

Figure 3: Natives' Employment Rate, 1989-1999 


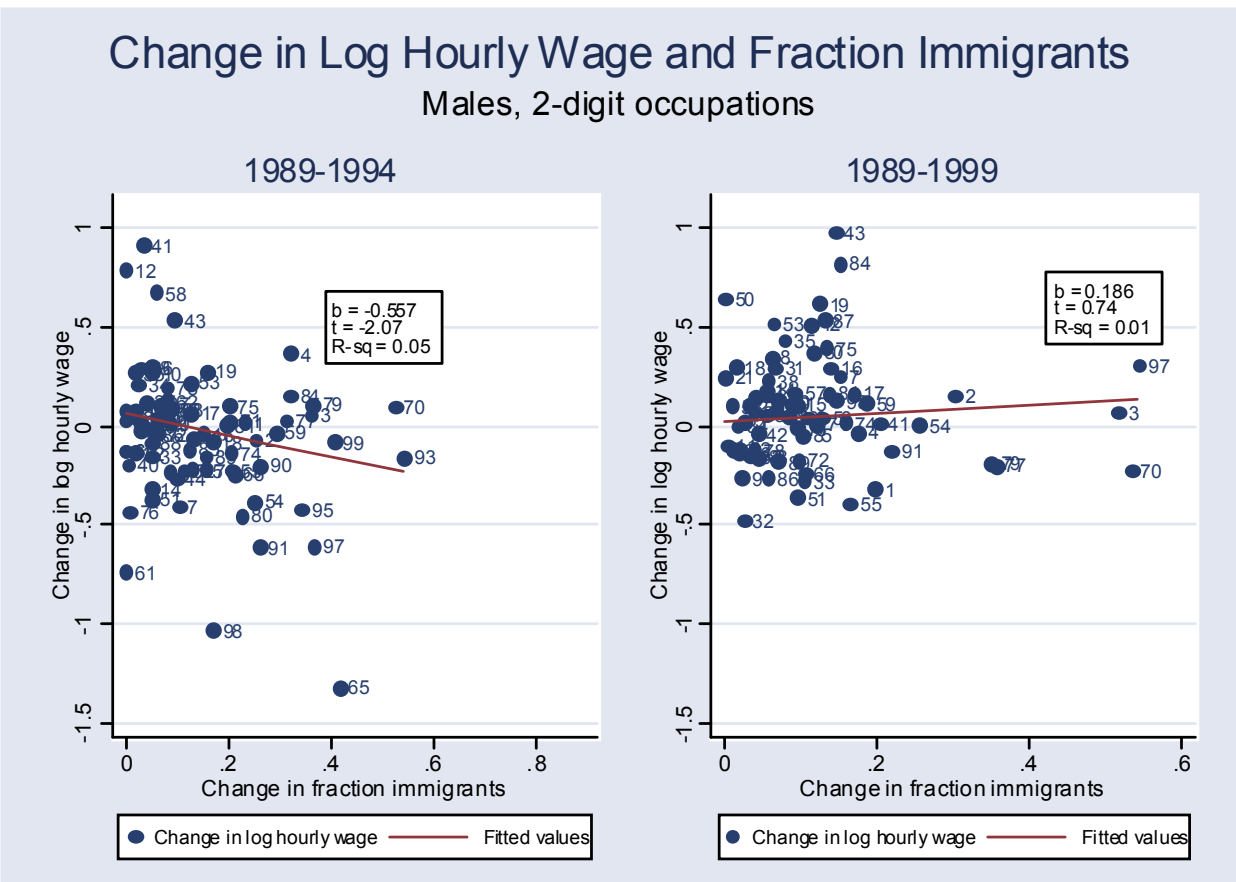

Figure 4: Change in Log Hourly Wages and Fraction of 1989-1991 Immigrants Males, 2-digit occupations

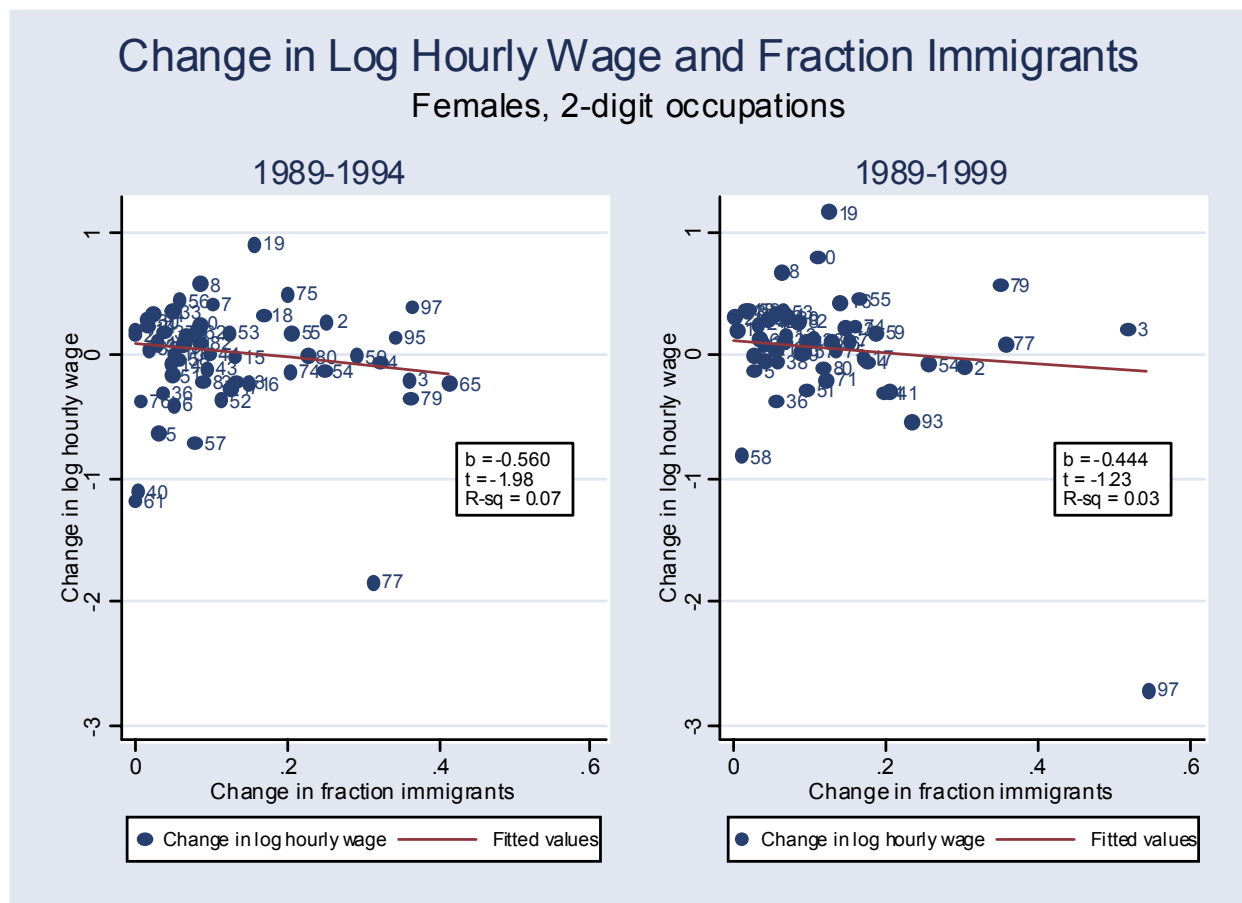

Figure 5: Change in Log Hourly Wages and Fraction of 1989-1991 Immigrants Females, 2-digit occupations 
Change in Employment Rate and Fraction Immigrants males, 2-digit occupations

1989-1994

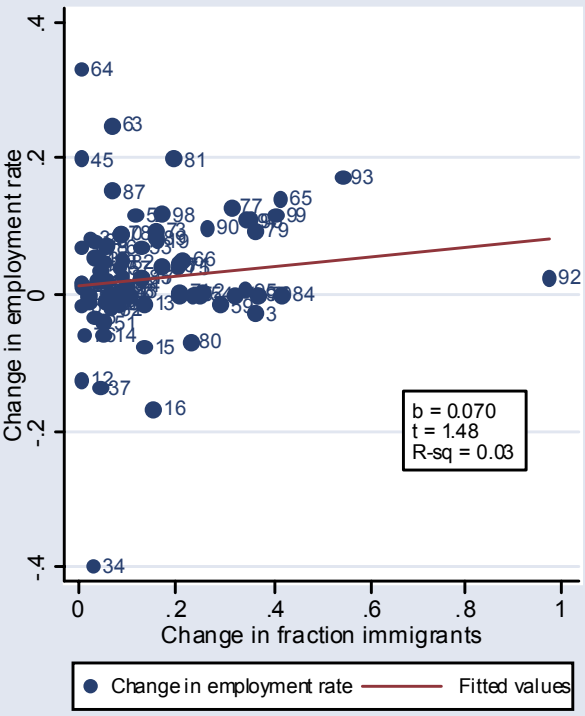

1989-1994

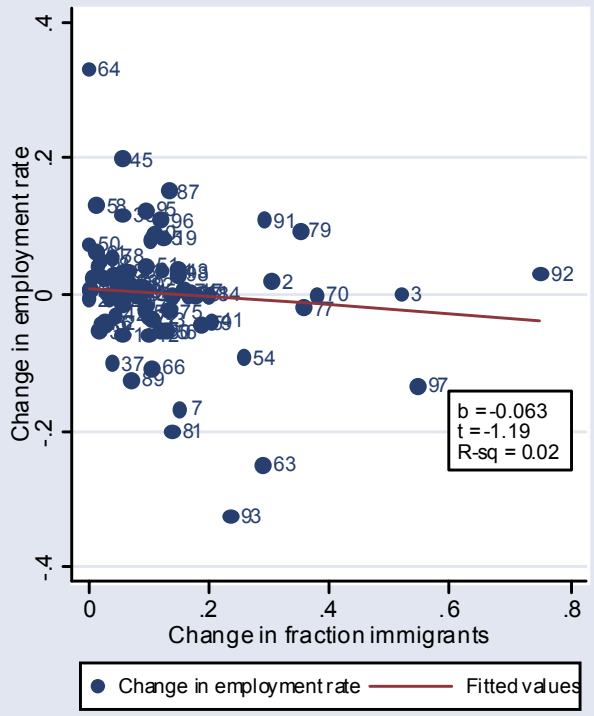

Figure 6: Change in Employment Rates and Fraction of 1989-1991 Immigrants Males, 2-digit occupations

Change in Employment Rate and Fraction Immigrants

Females, 2-digit occupations
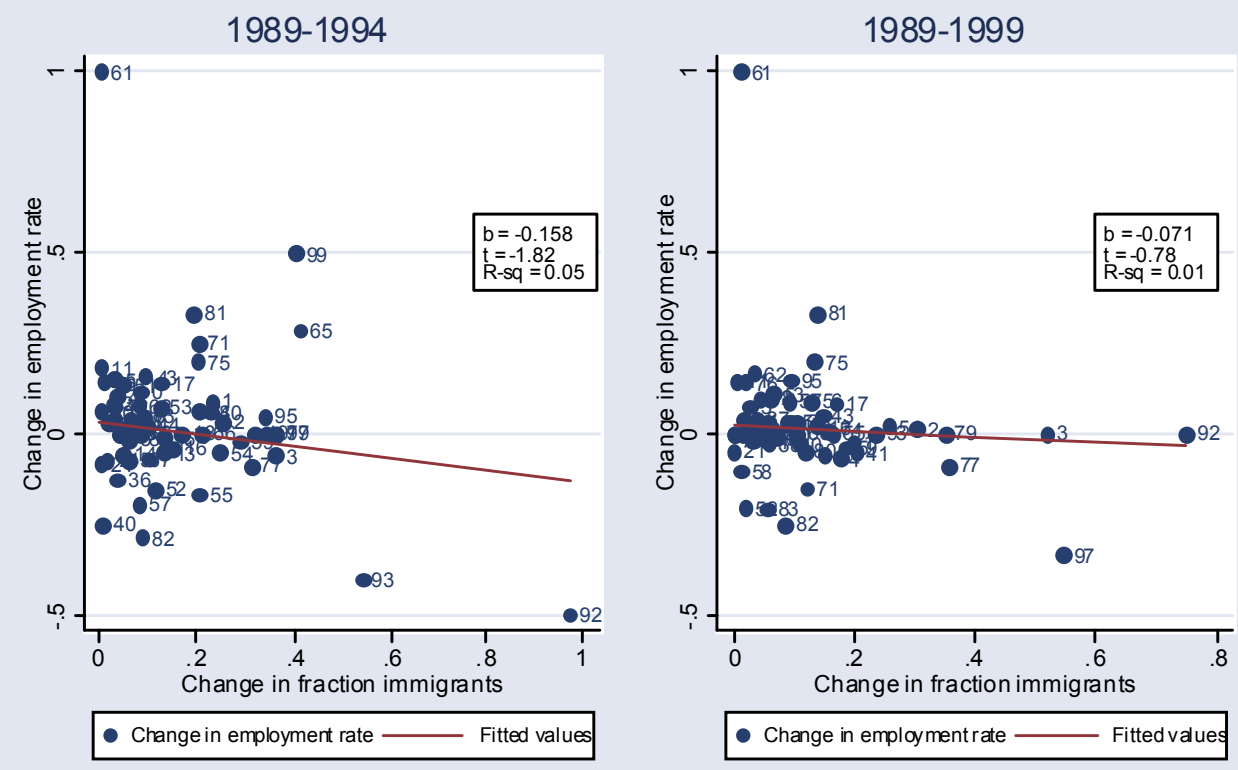

Figure 7: Change in Employment Rates and Fraction of 1989-1991 Immigrants Females, 2-digit occupations 
Table 1: Educational Distribution of Immigrants and Natives

\begin{tabular}{lcccc}
\hline \multicolumn{1}{c}{ Panel A: Males } & $\begin{array}{c}\text { All immigrants } \\
1989-1999\end{array}$ & $\begin{array}{c}\text { Immigrated in } \\
1989-1993\end{array}$ & $\begin{array}{c}\text { Immigrated in } \\
1994-1999\end{array}$ & Natives \\
\hline $\begin{array}{c}\text { Less than } \\
\text { High School }\end{array}$ & 9.54 & 8.33 & 11.18 & 32.40 \\
$\begin{array}{c}\text { High School } \\
\text { or Equivalent }\end{array}$ & 20.93 & 18.57 & 24.89 & 28.87 \\
$\begin{array}{c}\text { Some College } \\
\begin{array}{c}\text { College or } \\
\text { more }\end{array}\end{array}$ & 25.15 & 24.26 & 26.37 & 15.72 \\
\hline
\end{tabular}

Panel B: Females

\begin{tabular}{ccccc} 
& $\begin{array}{c}\text { All immigrants } \\
1989-1999\end{array}$ & $\begin{array}{c}\text { Immigrated in } \\
1989-1993\end{array}$ & $\begin{array}{c}\text { Immigrated in } \\
1994-1999\end{array}$ & Natives \\
\hline $\begin{array}{c}\text { Less than } \\
\text { High School }\end{array}$ & 8.43 & 7.77 & 8.81 & 29.26 \\
$\begin{array}{c}\text { High School } \\
\text { or Equivalent }\end{array}$ & 18.13 & 16.21 & 21.31 & 29.95 \\
$\begin{array}{c}\text { Some College } \\
\text { College or } \\
\text { more }\end{array}$ & 29.66 & 27.58 & 32.73 & 18.95 \\
\hline
\end{tabular}

Source: Authors' calculations from the Israeli Labor Force Survey, 1989-1999. 
Table 2: Occupational Distribution of Immigrants and Natives

\begin{tabular}{lcccc}
\hline & \multicolumn{2}{c}{$\mathbf{1 9 8 9 - 1 9 9 3}$} & \multicolumn{2}{c}{$\mathbf{1 9 9 4 - 1 9 9 9}$} \\
& All immigrants & Natives & All immigrants & Natives \\
\hline $\begin{array}{l}\text { Academic and } \\
\text { Scientific }\end{array}$ & 12.02 & 9.41 & 12.94 & 10.16 \\
$\begin{array}{l}\text { Professionals } \\
\text { Associate }\end{array}$ & 8.26 & 10.92 & 10.02 & 11.87 \\
$\begin{array}{l}\text { Professionals } \\
\text { Managers }\end{array}$ & 0.40 & 8.61 & & \\
Clerical Workers & 1.56 & 9.14 & 1.74 & 9.60 \\
Sales Workers & 2.34 & 9.75 & 3.34 & 9.19 \\
Service Workers & 14.17 & 8.16 & 3.45 & 9.68 \\
$\begin{array}{l}\text { Skilled } \\
\text { Agricultural }\end{array}$ & 3.47 & 4.60 & 13.52 & 9.48 \\
Workers & & & 5.03 & 4.20 \\
$\begin{array}{l}\text { Skilled Industry } \\
\text { Workers }\end{array}$ & 44.12 & 36.03 & & \\
Unskilled Workers & 13.66 & 3.39 & 41.88 & 33.46 \\
\hline
\end{tabular}

Panel B:

Females

1989-1993

1994-1999

All immigrants

Natives

All immigrants

Natives

Academic and

Scientific

9.03

9.49

10.39

10.04

Professionals

Associate

14.40

26.51

13.79

25.68

Professionals

\begin{tabular}{|c|c|c|c|c|}
\hline Managers & 0.42 & 2.49 & 0.70 & 3.59 \\
\hline Clerical Workers & 7.82 & 27.62 & 9.90 & 30.09 \\
\hline Sales Workers & 4.99 & 7.71 & 6.37 & 7.47 \\
\hline Service Workers & 36.75 & 18.17 & 36.30 & 17.48 \\
\hline $\begin{array}{l}\text { Skilled } \\
\text { Agricultural } \\
\text { Workers }\end{array}$ & 2.24 & 1.27 & 3.79 & 1.21 \\
\hline $\begin{array}{l}\text { Skilled Industry } \\
\text { Workers }\end{array}$ & 15.37 & 5.42 & 13.83 & 3.74 \\
\hline Unskilled Workers & 8.97 & 1.32 & 4.94 & 0.70 \\
\hline
\end{tabular}

Source: Authors' calculations from the Israeli Labor Force Survey 
Table 3: Residential Distribution of Immigrants and Natives

\begin{tabular}{ccccc}
\hline Panel A: Males & \multicolumn{2}{c}{ 1989-1993 } & \multicolumn{2}{c}{ 1994-1999 } \\
& All immigrants & Natives & All immigrants & Natives \\
\hline Jerusalem & 7.08 & 10.44 & 5.17 & 10.11 \\
North & 13.33 & 16.68 & 13.29 & 17.56 \\
Haifa & 17.98 & 13.86 & & 13.32 \\
$\begin{array}{c}\text { Tel Aviv } \\
\text { (outer circle) }\end{array}$ & 23.58 & 22.55 & 16.03 & 23.77 \\
$\begin{array}{c}\text { Tel Aviv } \\
\text { (inner circle) }\end{array}$ & 20.61 & & 21.90 & \\
South & 16.20 & 23.68 & & 21.52 \\
& 1.23 & 10.88 & & 17.96 \\
West Bank & & & 23.09 & \\
\hline
\end{tabular}

\section{Panel B: Females}

1989-1993

1994-1999

All immigrants

Natives

All immigrants

Natives

\begin{tabular}{ccccc} 
& All immigrants & Natives & All immigrants & Natives \\
\hline Jerusalem & 8.23 & 11.49 & 5.78 & 11.32 \\
North & 13.26 & 15.98 & 13.07 & 16.93 \\
Haifa & 18.33 & 13.44 & 16.45 & 13.13 \\
$\begin{array}{c}\text { Tel Aviv } \\
\text { (outer circle) }\end{array}$ & 23.47 & 22.08 & & \\
$\begin{array}{c}\text { Tel Aviv } \\
\text { (inner circle) }\end{array}$ & 19.21 & 24.60 & 20.78 & 23.43 \\
South & 16.20 & 10.46 & 18.10 & \\
& 1.30 & 1.95 & 23.31 & 11.03 \\
West Bank & & & & \\
& & & & 2.18 \\
\hline
\end{tabular}

Source: Authors' calculations from the Israeli Labor Force Survey 


\begin{tabular}{|c|c|c|}
\hline & Males & Females \\
\hline Employed (\% of the population) & 80.24 & 57.30 \\
\hline Education & 11.87 & 11.59 \\
\hline Experience & 24.51 & 23.03 \\
\hline Percentage married & 82.45 & 80.30 \\
\hline Number of children aged $0-4$ & 0.437 & 0.447 \\
\hline Number of children aged 5-14 & 0.896 & 0.995 \\
\hline Number of children aged 15-17 & 0.275 & 0.296 \\
\hline Percentage of Non-Jews & 13.89 & 13.73 \\
\hline Origin Asia-Africa $^{*}$ & 44.57 & 44.14 \\
\hline Origin Europe-America $^{*}$ & 32.85 & 33.11 \\
\hline Percentage foreign born & 37.82 & 36.08 \\
\hline Years in Israel (foreign born) & 33.67 & 31.72 \\
\hline Employed in public sector $(\%)$ & 17.83 & 46.95 \\
\hline $\begin{array}{l}\text { Total number of natives in LFS } \\
\text { sample }\end{array}$ & 58,485 & 59,263 \\
\hline Hourly wage (2000 NIS) ${ }^{* *}$ & 44.99 & 36.44 \\
\hline Log hourly wage (2000 NIS) ${ }^{* *}$ & 3.55 & 3.36 \\
\hline $\begin{array}{c}\text { Total Number of natives in Income } \\
\text { Survey sample }\end{array}$ & 40,372 & 42,437 \\
\hline
\end{tabular}

Source: Authors' calculations from the Israeli Labor Force and Income surveys, 1989-1999.

* Origin of respondent or respondent's father.

** In 2000, 1 US\$ = 4.07 NIS. 
Table 5: Immigrant Ratio by Labor Market Segmentation*

\begin{tabular}{|c|c|c|c|c|}
\hline Segmentation & Mean & Std.dev. & $\begin{array}{l}\text { Minimum } \\
\text { value }\end{array}$ & $\begin{array}{l}\text { Maximum } \\
\text { value }\end{array}$ \\
\hline $\begin{array}{l}\text { Two Digit } \\
\text { Occupation }\end{array}$ & 0.1439 & 0.2715 & 0 & 4.4117 \\
\hline $\begin{array}{l}\text { District of } \\
\text { Residence } \times \\
\text { Occupation }\end{array}$ & 0.1247 & 0.1440 & 0 & 1.0997 \\
\hline $\begin{array}{l}\text { Schooling } \times \\
\text { Occupation }\end{array}$ & 0.1477 & 0.3580 & 0 & 8.3078 \\
\hline $\begin{array}{l}\text { Industry } \times \\
\text { Occupation }\end{array}$ & 0.1413 & 0.4136 & 0 & 10.7266 \\
\hline $\begin{array}{l}\text { Schooling } \times \\
\text { Experience }\end{array}$ & 0.1593 & 0.2201 & 0 & 1.9092 \\
\hline
\end{tabular}


Table 6: The Effect of Immigration on Native Wages:

Constant and Dynamic Effects

\begin{tabular}{|c|c|c|c|c|c|c|}
\hline & \multicolumn{2}{|c|}{ Constant Effect } & \multicolumn{4}{|c|}{ Dynamic Effect } \\
\hline & \multirow[t]{2}{*}{ (1) } & \multirow[t]{2}{*}{ (2) } & \multicolumn{2}{|c|}{ (3) } & \multicolumn{2}{|c|}{ (4) } \\
\hline & & & $\begin{array}{c}\lambda_{0}: \text { Initial } \\
\text { Effect }\end{array}$ & $\begin{array}{l}\lambda_{1} \text { : Change } \\
\text { over time }\end{array}$ & $\begin{array}{c}\lambda_{0}: \text { Initial } \\
\text { Effect }\end{array}$ & $\begin{array}{c}\lambda_{1}: \text { Change } \\
\text { over time }\end{array}$ \\
\hline \multicolumn{7}{|l|}{ Panel A: Males } \\
\hline Two Digit Occupation & $\begin{array}{l}-0.0085 \\
{[-0.5734]}\end{array}$ & $\begin{array}{c}-0.0042 \\
{[-0.0964]}\end{array}$ & $\begin{array}{c}-0.3066 \\
{[-4.9548]}\end{array}$ & $\begin{array}{c}0.0678 \\
{[5.0404]}\end{array}$ & $\begin{array}{c}-0.2032 \\
{[-2.9052]}\end{array}$ & $\begin{array}{c}0.0393 \\
{[3.8904]}\end{array}$ \\
\hline $\begin{array}{l}\text { District of Residence } \times \\
\text { Occupation }\end{array}$ & $\begin{array}{c}-0.4429 \\
{[-11.1640]}\end{array}$ & $\begin{array}{c}-0.1847 \\
{[-3.4650]}\end{array}$ & $\begin{array}{c}-0.8771 \\
{[-9.1291]}\end{array}$ & $\begin{array}{c}0.1088 \\
{[4.5575]}\end{array}$ & $\begin{array}{c}-0.2743 \\
{[-2.5579]}\end{array}$ & $\begin{array}{c}0.0205 \\
{[0.9522]}\end{array}$ \\
\hline Schooling $\times$ Occupation & $\begin{array}{l}-0.0990 \\
{[-7.9195]}\end{array}$ & $\begin{array}{c}-0.0234 \\
{[-1.1353]}\end{array}$ & $\begin{array}{c}-0.2110 \\
{[-4.1457]}\end{array}$ & $\begin{array}{c}0.0270 \\
{[2.4256]}\end{array}$ & $\begin{array}{c}-0.0081 \\
{[-0.1810]}\end{array}$ & $\begin{array}{c}-0.0032 \\
{[-0.3648]}\end{array}$ \\
\hline Industry $\times$ Occupation & $\begin{array}{c}-0.0540 \\
{[-4.7233]}\end{array}$ & $\begin{array}{c}-0.0150 \\
{[-0.6610]}\end{array}$ & $\begin{array}{c}-0.3231 \\
{[-4.7542]}\end{array}$ & $\begin{array}{c}0.0631 \\
{[4.4093]}\end{array}$ & $\begin{array}{c}-0.1615 \\
{[-3.4668]}\end{array}$ & $\begin{array}{c}0.0309 \\
{[3.3457]}\end{array}$ \\
\hline Schooling $\times$ Experience & $\begin{array}{c}0.4079 \\
{[13.4580]}\end{array}$ & $\begin{array}{c}0.0813 \\
{[1.9867]}\end{array}$ & $\begin{array}{c}0.6284 \\
{[8.3661]}\end{array}$ & $\begin{array}{c}-0.0442 \\
{[-3.1045]}\end{array}$ & $\begin{array}{c}0.1179 \\
{[1.2325]}\end{array}$ & $\begin{array}{c}-0.0062 \\
{[-0.4103]}\end{array}$ \\
\hline Cell Fixed Effects & No & Yes & & Jo & & Tes \\
\hline
\end{tabular}

Constant Effect

(1) (2)
Dynamic Effect

(3)

(4)

\begin{tabular}{|c|c|c|c|c|c|c|}
\hline & & & $\begin{array}{l}\lambda_{0}: \text { Initial } \\
\text { Effect }\end{array}$ & $\begin{array}{l}\lambda_{1}: \text { Change } \\
\text { over time }\end{array}$ & $\begin{array}{l}\lambda_{0} \text { : Initial } \\
\text { Effect }\end{array}$ & $\begin{array}{l}\lambda_{1}: \text { Change } \\
\text { over time }\end{array}$ \\
\hline \multicolumn{7}{|l|}{ Panel B: Females } \\
\hline Two Digit Occupation & $\begin{array}{l}-0.2316 \\
{[-7.5853]}\end{array}$ & $\begin{array}{l}-0.1152 \\
{[-2.6113]}\end{array}$ & $\begin{array}{c}-0.7131 \\
{[-5.8049]}\end{array}$ & $\begin{array}{l}0.1131 \\
{[4.7091]}\end{array}$ & $\begin{array}{l}-0.2836 \\
{[-3.6148]}\end{array}$ & $\begin{array}{l}0.0352 \\
{[2.4002]}\end{array}$ \\
\hline $\begin{array}{l}\text { District of Residence } \times \\
\text { Occupation }\end{array}$ & $\begin{array}{c}-0.6054 \\
{[-10.6274}\end{array}$ & $\begin{array}{l}-0.2775 \\
{[-4.1059]}\end{array}$ & $\begin{array}{c}-1.5476 \\
{[-11.7495]}\end{array}$ & $\begin{array}{c}0.2344 \\
{[7.4842]}\end{array}$ & $\begin{array}{l}-0.5668 \\
{[-3.9403]}\end{array}$ & $\begin{array}{l}0.0651 \\
{[2.4484]}\end{array}$ \\
\hline Schooling $\times$ Occupation & $\begin{array}{l}-0.1203 \\
{[-5.5008]}\end{array}$ & $\begin{array}{c}-0.0624 \\
{[-1.9418]}\end{array}$ & $\begin{array}{l}-0.2837 \\
{[-2.9224]}\end{array}$ & $\begin{array}{l}0.0446 \\
{[1.9137]}\end{array}$ & $\begin{array}{c}-0.1354 \\
{[-1.9038]}\end{array}$ & $\begin{array}{l}0.0156 \\
{[1.1764]}\end{array}$ \\
\hline Industry $\times$ Occupation & $\begin{array}{l}-0.0740 \\
{[-5.1300]}\end{array}$ & $\begin{array}{l}-0.0675 \\
{[-2.6740]}\end{array}$ & $\begin{array}{l}-0.3219 \\
{[-3.9293]}\end{array}$ & $\begin{array}{l}0.0594 \\
{[3.3342]}\end{array}$ & $\begin{array}{l}-0.1249 \\
{[-2.0604]}\end{array}$ & $\begin{array}{l}0.0118 \\
{[1.0749]}\end{array}$ \\
\hline Schooling $\times$ Experience & $\begin{array}{c}0.5021 \\
{[14.7259]}\end{array}$ & $\begin{array}{l}0.1165 \\
{[2.4793]}\end{array}$ & $\begin{array}{c}0.9215 \\
{[10.8672]}\end{array}$ & $\begin{array}{l}-0.0799 \\
{[-5.3979]}\end{array}$ & $\begin{array}{l}0.1593 \\
{[1.5166]}\end{array}$ & $\begin{array}{l}-0.0069 \\
{[-0.4477]}\end{array}$ \\
\hline
\end{tabular}

\begin{tabular}{llll}
\hline Cell Fixed Effects & No & Yes & No
\end{tabular}

Dependent variable: log hourly wages. Entries in the table represent the parameter estimate, standard errors (in parentheses) and t-statistics (in brackets) for the coefficient on the fraction immigrants in a labor market segment from separate regressions. Standard errors are robust to general heteroskedasticity and clustering at the segment-calendar quarter level. Sample sizes: around 24,200 for males; around 19,300 for females.

The sample is an extract from the 1989-1999 Israeli Income Survey, and includes all natives and pre-1989 immigrants for whom data on occupation is non-missing. The male sample is restricted to ages 25 to 65 , the female sample is restricted to ages 25 to 60. All regressions include the following variables: total employment in the segment, an index of labor demand for workers in the segment (see text for details, education, experience, experience squared; a dummy for married; dummies for the number of children between 0 and 4, between 5 and 14, and between 15 and 17; a dummy for non-Jews; dummies for ethnic origin AsiaAfrica and ethnic origin Europe-America-Oceania (third generation Israelis are the omitted category); a dummy for foreign born status and years since immigration (zero for natives); a full set of calendar quarter dummies. Observations with missing data were deleted. 


\section{Table 7: The Effect of Immigration on Native Employment: Constant and Dynamic Effects}

\begin{tabular}{lccccccc}
\hline & \multicolumn{2}{c}{ Constant Effect } & \multicolumn{5}{c}{ Dynamic Effect } \\
\hline & $(1)$ & $(2)$ & \multicolumn{2}{c}{$(3)$} & $(4)$ \\
& & & $\begin{array}{c}\lambda_{0} \text { : Initial } \\
\text { Effect }\end{array}$ & $\begin{array}{c}\lambda_{1} \text { : Change } \\
\text { over time }\end{array}$ & $\begin{array}{c}\lambda_{0} \text { : Initial } \\
\text { Effect }\end{array}$ & $\begin{array}{c}\lambda_{1} \text { : Change } \\
\text { over time }\end{array}$ \\
\hline Panel A: Males & & & & & & & \\
Two Digit Occupation & -0.0114 & 0.0099 & -0.0602 & 0.0112 & 0.0229 & -0.0027 \\
& {$[-2.4835]$} & {$[0.9600]$} & {$[-3.8247]$} & {$[3.4187]$} & {$[1.1058]$} & {$[-0.8216]$} \\
District of Residence $\times$ & -0.0512 & -0.0054 & -0.1067 & 0.0137 & -0.0365 & 0.0070 \\
Occupation & {$[-5.6237$} & {$[-0.3500]$} & {$[-4.2082]$} & {$[2.5578]$} & {$[-1.1149]$} & {$[1.1902]$} \\
& -0.0159 & -0.0075 & -0.0229 & 0.0017 & -0.0102 & 0.0006 \\
Schooling $\times$ Occupation & {$[-4.1643]$} & {$[-0.9452]$} & {$[-2.1468]$} & {$[0.6603]$} & {$[-0.6012]$} & {$[0.1935]$} \\
& -0.0053 & 0.0094 & -0.0418 & 0.0084 & 0.0169 & -0.0016 \\
Industry Occupation & {$[-1.7757]$} & {$[0.943]$} & {$[-2.4779]$} & {$[2.2768]$} & {$[0.8795]$} & {$[-0.5225]$} \\
& -0.0070 & -0.0042 & -0.0581 & 0.0101 & -0.0671 & 0.0106 \\
Schooling $\times$ Experience & {$[-1.0455]$} & {$[-0.4039]$} & {$[-3.3753]$} & {$[3.3466]$} & {$[-3.1111]$} & {$[3.2909]$} \\
\hline Cell fixed effects & \multirow{2}{*}{ No } & \multirow{2}{*}{ Yes } & & No & \multicolumn{2}{c}{ Yes } \\
\hline
\end{tabular}

Constant Effect

(1)
(2)

\section{Dynamic Effect}

(3)
(4)

$\lambda_{0}$ : Initial $\lambda_{1}$ : Change $\lambda_{0}$ : Initial $\lambda_{1}$ : Change Effect over time Effect over time

\begin{tabular}{|c|c|c|c|c|c|c|}
\hline Two Digit Occupation & $\begin{array}{c}-0.0380 \\
{[-4.2161]}\end{array}$ & $\begin{array}{l}0.0667 \\
{[3.7612]}\end{array}$ & $\begin{array}{l}-0.1121 \\
{[-3.5431]}\end{array}$ & $\begin{array}{c}0.0174 \\
{[2.4988]}\end{array}$ & $\begin{array}{c}0.087 \\
{[2.0740]}\end{array}$ & $\begin{array}{l}-0.0044 \\
{[-0.5558]}\end{array}$ \\
\hline $\begin{array}{l}\text { District of Residence } \times \\
\text { Occupation }\end{array}$ & $\begin{array}{l}-0.0728 \\
{[-4.5491]}\end{array}$ & $\begin{array}{c}0.0330 \\
{[1.2394]}\end{array}$ & $\begin{array}{l}-0.2033 \\
{[-5.3082]}\end{array}$ & $\begin{array}{c}0.0317 \\
{[3.8946]}\end{array}$ & $\begin{array}{c}0.0739 \\
{[1.4314]}\end{array}$ & $\begin{array}{c}-0.009 \\
{[-0.9702]}\end{array}$ \\
\hline Schooling $\times$ Occupation & $\begin{array}{l}-0.0058 \\
{[-0.9803]}\end{array}$ & $\begin{array}{c}0.0077 \\
{[0.6847]}\end{array}$ & $\begin{array}{l}-0.0390 \\
{[-1.8871]}\end{array}$ & $\begin{array}{c}0.0082 \\
{[1.5943]}\end{array}$ & $\begin{array}{c}0.0107 \\
{[0.3932]}\end{array}$ & $\begin{array}{l}-0.0006 \\
{[-0.1110]}\end{array}$ \\
\hline Industry $\times$ Occupation & $\begin{array}{l}-0.0052 \\
{[-1.1000]}\end{array}$ & $\begin{array}{c}0.0268 \\
{[1.7927]}\end{array}$ & $\begin{array}{l}-0.0647 \\
{[-2.5289]}\end{array}$ & $\begin{array}{l}0.0135 \\
{[2.5179]}\end{array}$ & $\begin{array}{c}0.0255 \\
{[1.0517]}\end{array}$ & $\begin{array}{l}0.0003 \\
{[0.0619]}\end{array}$ \\
\hline Schooling $\times$ Experience & $\begin{array}{c}0.0179 \\
{[1.9263]}\end{array}$ & $\begin{array}{c}-0.0157 \\
{[-1.0990]}\end{array}$ & $\begin{array}{c}0.0446 \\
{[1.6823]}\end{array}$ & $\begin{array}{c}-0.005 \\
{[-1.0968]}\end{array}$ & $\begin{array}{c}-0.0457 \\
{[-1.3015]}\end{array}$ & $\begin{array}{c}0.0048 \\
{[0.9537]}\end{array}$ \\
\hline
\end{tabular}

Cell fixed effects

No $\quad$ Yes

No

Yes

Dependent variable: 1 if employed, 0 otherwise. Entries in the table represent the parameter estimate and t-statistics (in brackets) for the coefficient on the fraction immigrants in a labor market segment from separate linear probability models. Standard errors are robust to general heteroskedasticity and clustering at the segment-calendar quarter level. Sample sizes: around 47,000 for males; around 35,500 for females.

The sample is an extract from the 1989-1999 Israeli Labor Force Survey, and includes all natives and pre-1989 immigrants in their first LFS interview for whom data on occupation is non-missing. The male sample is restricted to ages 25 to 65 , the female sample is restricted to ages 25 to 60 . All regressions include the following variables: total employment in the segment, an index of labor demand for workers in the segment (see text for details, education, experience, experience squared; a dummy for married; dummies for the number of children between 0 and 4 , between 5 and 14, and between 15 and 17 ; a dummy for nonJews; dummies for ethnic origin Asia-Africa and ethnic origin Europe-America-Oceania (third generation Israelis are the omitted category); a dummy for foreign born status and years since immigration (zero for natives); a full set of calendar quarter dummies. Observations with missing data were deleted. 
Table 8: Immigrants Short-Run and Long-Run Effects on Natives' Wage:

\section{Robustness Checks}

(1)

(3)

(4)

Autocorrelation Robust Standard Errors

Adding Cohort Dummies

Cell Fixed Effects Interacted with Linear Time Trend

Cell Fixed Effects and One-digit Interactions with a Full Set of Year Dummies

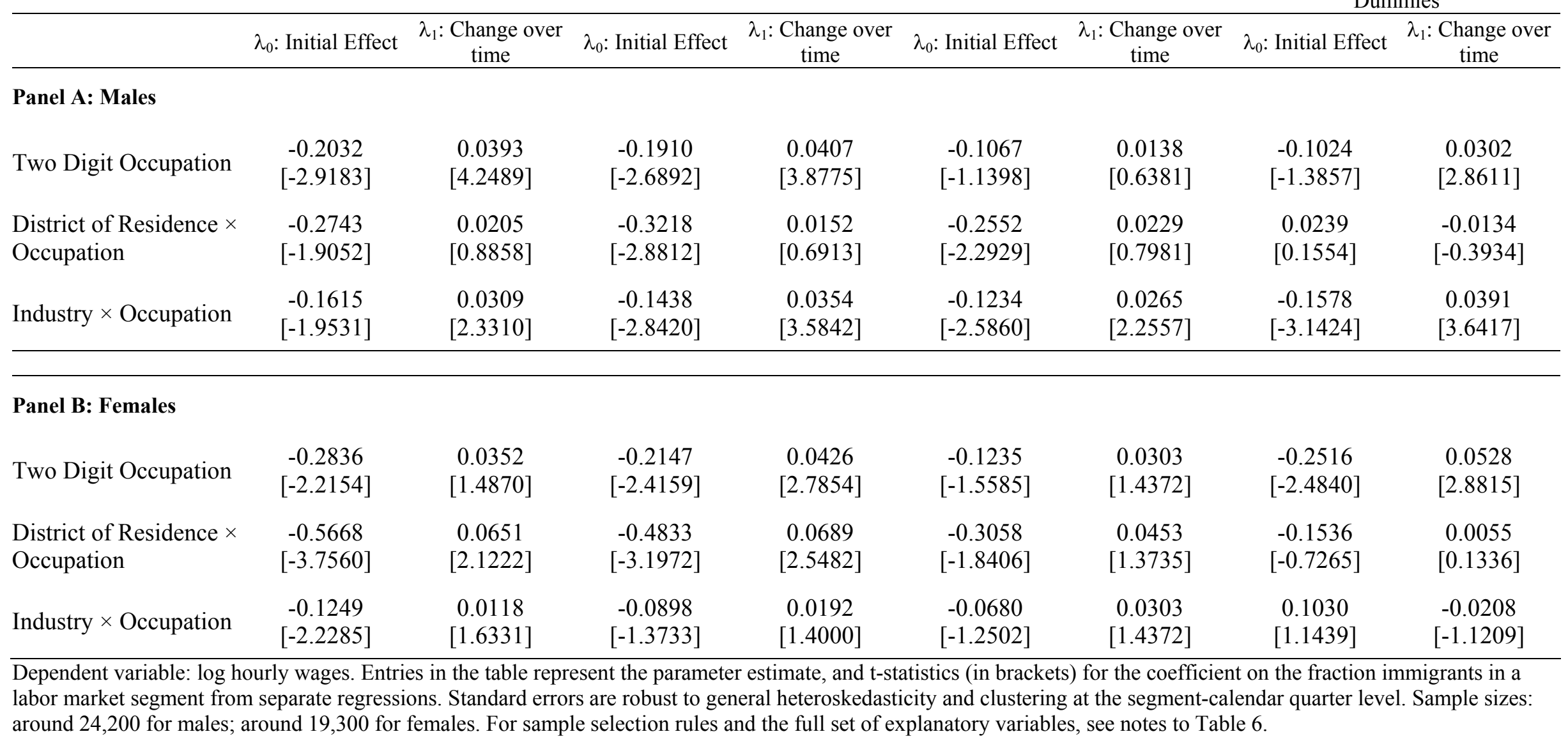


Table 9: Piecewise Constant Effects of Immigration on Native Wages

\begin{tabular}{|c|c|c|c|c|c|c|c|c|}
\hline & \multicolumn{4}{|c|}{$\begin{array}{c}(1) \\
\text { Cell Fixed Effects }\end{array}$} & \multicolumn{4}{|c|}{$\begin{array}{c}(2) \\
\text { Cell Fixed Effects Interacted with Linear Trend }\end{array}$} \\
\hline & $\begin{array}{l}\text { Effect at } 0 \\
\text { years }\end{array}$ & $\begin{array}{l}\text { Effect at } 1-3 \\
\text { years }\end{array}$ & $\begin{array}{l}\text { Effect at } 4-6 \\
\text { years }\end{array}$ & $\begin{array}{l}\text { Effect at } 7-10 \\
\text { years }\end{array}$ & $\begin{array}{l}\text { Effect at } 0 \\
\text { years }\end{array}$ & $\begin{array}{l}\text { Effect at } 1-3 \\
\text { years }\end{array}$ & $\begin{array}{l}\text { Effect at } 4-6 \\
\text { years }\end{array}$ & $\begin{array}{l}\text { Effects at } 7-10 \\
\text { years }\end{array}$ \\
\hline \multicolumn{9}{|l|}{ Panel A: Males } \\
\hline $\begin{array}{l}\text { Two Digit } \\
\text { Occupation }\end{array}$ & $\begin{array}{r}-0.2862 \\
{[-1.33]}\end{array}$ & $\begin{array}{l}-0.1792 \\
{[-2.67]}\end{array}$ & $\begin{array}{l}0.0471 \\
{[0.82]}\end{array}$ & $\begin{array}{r}0.1087 \\
{[2.12]}\end{array}$ & $\begin{array}{r}-0.2614 \\
{[-1.10]}\end{array}$ & $\begin{array}{r}-0.1295 \\
{[-2.00]}\end{array}$ & $\begin{array}{r}0.0100 \\
{[0.17]}\end{array}$ & $\begin{array}{r}-0.0219 \\
{[-0.19]}\end{array}$ \\
\hline $\begin{array}{l}\text { District of } \\
\text { Residence } \times \\
\text { Occupation }\end{array}$ & $\begin{array}{r}0.1474 \\
{[0.44]}\end{array}$ & $\begin{array}{r}-0.3158 \\
{[-3.32]}\end{array}$ & $\begin{array}{r}-0.1261 \\
{[-1.29]}\end{array}$ & $\begin{array}{r}-0.1016 \\
{[-0.87]}\end{array}$ & $\begin{array}{r}0.0216 \\
{[0.06]}\end{array}$ & $\begin{array}{r}-0.3149 \\
{[-3.08]}\end{array}$ & $\begin{array}{r}-0.0143 \\
{[-0.11]}\end{array}$ & $\begin{array}{r}-0.0414 \\
{[-0.22]}\end{array}$ \\
\hline $\begin{array}{l}\text { Industry } \times \\
\text { Occupation }\end{array}$ & $\begin{array}{r}-0.7288 \\
{[-2.98]}\end{array}$ & $\begin{array}{r}-0.1399 \\
{[-2.94]}\end{array}$ & $\begin{array}{r}0.0480 \\
{[1.49]}\end{array}$ & $\begin{array}{r}0.0977 \\
{[2.32]}\end{array}$ & $\begin{array}{r}-0.6877 \\
{[-2.87]}\end{array}$ & $\begin{array}{r}-0.1075 \\
{[-2.21]}\end{array}$ & $\begin{array}{r}0.0428 \\
{[1.29]}\end{array}$ & $\begin{array}{r}0.0271 \\
{[0.41]}\end{array}$ \\
\hline \multicolumn{9}{|c|}{ Panel B: Females } \\
\hline $\begin{array}{l}\text { Two Digit } \\
\text { Occupation }\end{array}$ & $\begin{array}{r}-0.2324 \\
{[-0.71]}\end{array}$ & $\begin{array}{r}-0.3105 \\
{[-3.49]}\end{array}$ & $\begin{array}{r}-0.0045 \\
{[-0.06]}\end{array}$ & $\begin{array}{r}-0.0163 \\
{[-0.21]}\end{array}$ & $\begin{array}{r}-0.1628 \\
{[-0.48]}\end{array}$ & $\begin{array}{l}-0.1713 \\
{[-1.78]}\end{array}$ & $\begin{array}{r}0.1376 \\
{[1.19]}\end{array}$ & $\begin{array}{r}0.0948 \\
{[0.59]}\end{array}$ \\
\hline $\begin{array}{l}\text { District of } \\
\text { Residence } \times \\
\text { Occupation }\end{array}$ & $\begin{array}{r}-0.0314 \\
{[-0.05]}\end{array}$ & $\begin{array}{r}-0.5053 \\
{[-4.22]}\end{array}$ & $\begin{array}{r}-0.2385 \\
{[-2.02]}\end{array}$ & $\begin{array}{r}-0.0072 \\
{[-0.06]}\end{array}$ & $\begin{array}{r}-0.1610 \\
{[-0.28]}\end{array}$ & $\begin{array}{r}-0.2896 \\
{[-2.01]}\end{array}$ & $\begin{array}{r}0.0045 \\
{[0.03]}\end{array}$ & $\begin{array}{r}0.0560 \\
{[0.28]}\end{array}$ \\
\hline $\begin{array}{l}\text { Industry } \times \\
\text { Occupation }\end{array}$ & $\begin{array}{r}0.6559 \\
{[1.41]}\end{array}$ & $\begin{array}{r}-0.1022 \\
{[-1.35]}\end{array}$ & $\begin{array}{c}-0.0933 \\
{[-1.42]}\end{array}$ & $\begin{array}{r}-0.0187 \\
{[-0.46]}\end{array}$ & $\begin{array}{r}0.5756 \\
{[1.19]}\end{array}$ & $\begin{array}{r}-0.0399 \\
{[-0.43]}\end{array}$ & $\begin{array}{r}-0.0357 \\
{[-0.42]}\end{array}$ & $\begin{array}{r}0.0476 \\
{[0.40]}\end{array}$ \\
\hline
\end{tabular}

Dependent variable: log hourly wages. Entries in the table represent the parameter estimate and t-statistics (in brackets) for the coefficient on the fraction immigrants in a labor market segment from separate regressions. Standard errors are robust to general heteroskedasticity and clustering at the segment-calendar quarter level. Sample sizes: around 24,200 for males; around 19,300 for females. For sample selection rules and the full set of explanatory variables, see notes to Table 6 . 